Article

\title{
Antiplasmodial Activity and In Vivo Bio-Distribution of Chloroquine Molecules Released with a 4-(4-Ethynylphenyl)-Triazole Moiety from Organometallo-Cobalamins
}

\author{
Jeremie Rossier ${ }^{1, \dagger}$, Sara Nasiri Sovari ${ }^{1,+}$, Aleksandar Pavic ${ }^{2,+}{ }^{\oplus}$, Sandra Vojnovic ${ }^{2}(\mathbb{D}$, \\ Tameryn Stringer ${ }^{3}$, Sarah Bättig ${ }^{1}$, Gregory S. Smith $\left.{ }^{3}{ }^{(}\right)$, Jasmina Nikodinovic-Runic ${ }^{2, *}{ }^{-1}$ and \\ Fabio Zobi ${ }^{1, *(1)}$ \\ 1 Department of Chemistry, University of Fribourg, Chemin du Musée 10, 1700 Fribourg, Switzerland; \\ jeremie.rossier@unifr.ch (J.R.); sara.nasirisovari@unifr.ch (S.N.S.); sarah.baettig@unifr.ch (S.B.) \\ 2 Institute of Molecular Genetics and Genetic Engineering, University of Belgrade, Vojvode Stepe 444a, \\ 11000 Belgrade, Republic of Serbia; pavicaleksandarr@gmail.com (A.P.); sanvojnov@gmail.com (S.V.) \\ 3 Department of Chemistry, University of Cape Town, Rondebosch 7701, South Africa; \\ STRTAM001@myuct.ac.za (T.S.); gregory.smith@uct.ac.za (G.S.S.) \\ * Correspondence: jasmina.nikodinovic@imgge.bg.ac.rs (J.N.-R.); fabio.zobi@unifr.ch (F.Z.); \\ Tel.: +381-113976034 (J.N.-R.); +41-26-300-8785 (F.Z.) \\ + These authors contributed equally to this work.
}

Academic Editor: Rafik Karaman

Received: 28 May 2019; Accepted: 19 June 2019; Published: 21 June 2019

\begin{abstract}
We have explored the possibility of using organometallic derivatives of cobalamin as a scaffold for the delivery of the same antimalarial drug to both erythro- and hepatocytes. This hybrid molecule approach, intended as a possible tool for the development of multi-stage antimalarial agents, pivots on the preparation of azide-functionalized drugs which, after coupling to the vitamin, are released with a 4-(4-ethynylphenyl)-triazole functionality. Three chloroquine and one imidazolopiperazine derivative (based on the KAF156 structure) were selected as model drugs. One hybrid chloroquine conjugate was extensively studied via fluorescent labelling for in vitro and in vivo bio-distribution studies and gave proof-of-concept for the design. It showed no toxicity in vivo (zebrafish model) as well as no hepatotoxicity, no cardiotoxicity or developmental toxicity of the embryos. All 4-(4-ethynylphenyl)-triazole derivatives of chloroquine were equally active against chloroquine-resistant (CQR) and chloroquine-sensitive (CQS) Plasmodium falciparum strains.
\end{abstract}

Keywords: antimalarial; prodrug; chloroquine; triazole; cobalamin; in vivo; zebrafish model

\section{Introduction}

Malaria is considered to be one of the most life-threatening and globally infectious diseases caused by a single-cell parasite called Plasmodium (including P. falciparum, P. vivax, P. ovale, P. malariae). This disease has remained one of the leading causes of morbidity and mortality over the past centuries throughout the world. According to the World Health Organization (WHO) in 2016, there have been about 216 million cases of malaria and 445,000 deaths worldwide [1]. A decrease of $4 \%$ annually in the number of malaria victims over the past decade was observed, and clinical malaria cases have declined from 2000 to 2015 in endemic parts of Africa. However, P. falciparum, the most lethal malaria species in humans, has become resistant to the most conventional antimalarial treatments, in turn resulting in a worldwide concern and the call for new strategies, and drugs that can act at different stages of the parasite life cycle [2-4]. 
New drug candidates are being identified as a result of the combined efforts of a global consortium (known as the NGBS (The NGBS consortium in malaria drug discovery is a collaboration between the Novartis Institute for Tropical Diseases (NITD), the Genomics Institute of the Novartis Research Foundation (GNF), the Biomedical Primate Research Centre (BPRC) and the Swiss Tropical and Public Health Institute (SwissTPH)) consortium) with the help of industry and private-public partnerships and by leading pharmaceutical companies (like Novartis or GlaxoSmithKline) that have the capacity for high-throughput screening of thousands of compounds [5]. These efforts have led to the chemical optimization of DDD107498 (Figure 1), a compound with a potent antimalarial activity against multiple life-cycle stages of the Plasmodium parasite and whose molecular target is the translation elongation factor 2 (eEF2), essential for parasite protein synthesis [6-8]. Other strategies being pursued involve the preparation of hybrid molecules to augment the activity profile of older drugs like chloroquine (CQ) [9]. In this approach, two different drug moieties, each with its own medicinal properties, are covalently linked in a single hybrid molecule, which presents a dual activity. The primaquine-chloroquine (PQ-CQ, Figure 1) hybrid reported by Lödige et al. exemplifies this approach [10]. The molecule displays in vitro activity against both asexual and sexual P. falciparum blood stages as well as $P$. berghei sporozoites and liver stages, and in vivo it is active against $P$. berghei liver and blood stages.

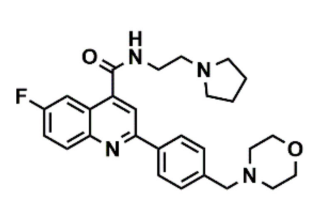

DDD107498

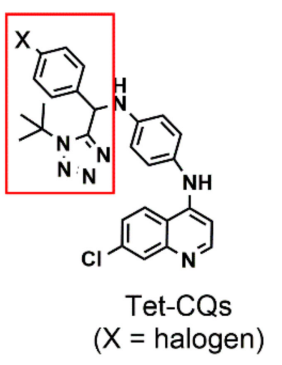

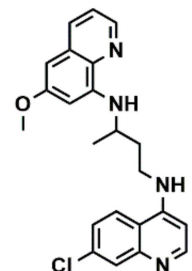

$P Q-C Q$

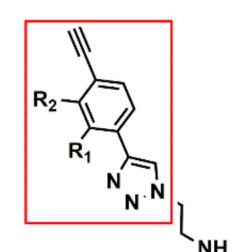

JR1-3
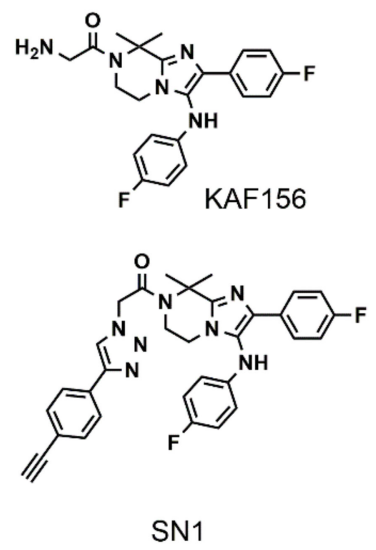

SN1

Figure 1. Molecular structures of antimalarial drugs mentioned in the introduction. JR1-3 and SN1 are the molecules designed for this study (vide infra for details). The red box indicates the structural feature that we took as reference for the design of the compounds.

Within this context, we decided to explore the possibility of using organometallic derivatives of cobalamin as a vector for antimalarial drugs as they were previously exploited for the targeted release of anticancer drugs [11-13]. For our study, we decided to evaluate triazole-containing chloroquinoline drugs, derivatized at the $\mathrm{N}$-alkyl amino side chain and one imidazolopiperazine derivative based on the KAF156 (Ganaplacide) structure (Figure 1) [14]. The latter was selected as it is a rare example of drugs effective at the liver stage. The design of the CQ molecules was developed starting from the reference tetrazole embedded CQ derivatives prepared by Pandey et al. (Tet-CQs in Figure 1) [15]. These derivatives are active in animal models showing between ca. 60 and $99.99 \%$ suppression of parasitaemia on the fourth day of treatment.

In our design, the CQ ring was left untouched, as this moiety is essential for the antimalarial activity of this class of compounds. Modifications of the CQ ring alter the $\mathrm{pKa}$ values of the whole molecule thereby affecting drug uptake by the parasite digestive vacuoles and its influx/efflux [16]. Modification at $N$-alkyl amino side chain are much less detrimental for the antimalarial activity the compounds [17]. Azoles were chosen because they are an important class of nitrogen containing heterocyclic compounds that often improve the therapeutic and biological activity of organic drugs. 
Their addition to the side chain of 7-chloro-4-aminoquinoline was suggested as a useful strategy for the design and development of new antimalarial agents [18]. Furthermore, tetrazole embedded CQ derivatives inhibit hemozoin possibly via heme complexation through the azole functionality [15] and, finally, triazole can be readily prepared via the $\mathrm{Cu}(\mathrm{I})$-catalyzed azide-alkyne cycloaddition, a synthetic approach applicable to vitamin $\mathrm{B}_{12}$ chemistry [19].

The use of cobalamin $\left(\mathrm{B}_{12}, \mathrm{Cbl}\right)$ as a vector of antimalarial drugs for both the hepatocytic and erythrocytic stages rests on the consideration that vitamin $\mathrm{B}_{12}$ is transported and stored in the liver and that naturally occurring cobalamins have antimalarial activity of their own with $\mathrm{IC}_{50}$ values (blood stage) ranging from ca. 2-130 $\mathrm{MM}$ [20]. As such, they might act synergistically with other antimalarial compounds. Among the naturally occurring Cbls, Ado-Cbl (adenosylcobalamin) is the most active, followed by $\mathrm{H}_{2} \mathrm{O}-, \mathrm{CH}_{3}$ - and $\mathrm{CN}-\mathrm{Cbl}$. Furthermore, with the exception of $\mathrm{CN}-\mathrm{Cbl}$, all derivatives are approximately forty times more effective than chloroquine in inhibiting hemozoin formation [20]. Erythrocyte uptake ca. $20-50 \mathrm{pg} \mathrm{B}$ 12 $_{2} / \mathrm{mL}$ (ca. 0.1-0.25 $\mu \mathrm{g} / 5 \mathrm{~L}$ human blood) [21]. The uptake depends on metabolic factors, it increases with rising reticulocyte count [22] and $\mathrm{B}_{12}$ content in red blood cells increases with levels of holoTCII ( $\mathrm{B}_{12}$-bound transcobalamin II protein complex recognized by cell for $B_{12}$ uptake) [23]. Finally, P. falciparum requires nanomolar concentrations of $B_{12}$ for optimal growth as a cofactor for methionine synthase [24], the only $\mathrm{B}_{12}$-dependant enzyme in the intra-erythrocytic P. falciparum [25]. Chemaly has suggested that infected erythrocytes may uptake cobalamin while still bound to transcobalamin II or possibly haptocorrin [20], because the parasite is known to reactivate dormant endogenous red blood cell transporters, increase the permeability of the erythrocytic membrane [26,27], and infected erythrocytes are able to incorporate molecules as large as transferrin (ca. $80 \mathrm{kDa}$ ) [28].

\section{Results and Discussion}

\subsection{Synthesis and Characterization}

Vitamin $\mathrm{B}_{12}\left(\mathrm{~B}_{12}, \mathrm{Cbl}\right)$ derivatives bearing antimalarial compounds were prepared by attaching releasable drugs at the cobalt ion via the synthetic protocol illustrated in Figure 2. The cyanide ligand of $\mathrm{Cbl}$ was substituted by either 1,4-diethynylbenzene [29] or 1,4-diethynyl-2-fluorobenzene to give cobalamine-1,4-diethynylbenzene $\left(\mathrm{B}_{12}-1\right)$ or the fluorinated cobalamine-1,4-diethynyl-fluorobenzene intermediates $\mathrm{B}_{12}-\mathbf{F 1}$ and -F2 [11,30]. Following these reactions, an absorbance at $2117 \mathrm{~cm}^{-1}$ in the IR spectrum of the species replaced the original $v C \equiv N$ frequency at $2134 \mathrm{~cm}^{-1}$ and was assigned to the cobalt-bound alkyne function. Concomitantly, the 4-diethylamino-1-methylbutylamino chain appended at the quinoline core structure of chloroquine was replaced by a 2-azidoethyl chain (to give $N$-(2-azidoethyl)-7-chloroquinolin-4-amine, $\mathrm{N}_{3}$-CQ) [31]. Similarly the primary amine of KAF156 was modified to a 2-azido-acetamide function giving 2-azido-1-(2-(4-fluorophenyl)-3-((4-fluorophenyl)amino)-8,8-dimethyl-5,6-dihydroimidazo[1-a]pyrazin$7(8 H)$-yl)ethan-1-one $\left(\mathrm{N}_{3}-\mathrm{SN1}, \quad\right.$ Figure 2) by using 2-azido-1,3-dimethylimidazolinium hexafluorophosphate and triethylamne in actetonitrile. This approach rendered the molecular units suitable for fusion via the $\mathrm{Cu}(\mathrm{I})$-catalyzed azide-alkyne cycloaddition. Overall, following HPLC purification, the cycloaddition reaction gave vitamin $B_{12}$ derivatives $\left(B_{12}-J R 1,2\right.$ and 3 and $B_{12}-S N 1$, Figure 2) in good yields (60-80\%).

The aromatic regions of the ${ }^{1} \mathrm{H}-\mathrm{NMR}$ spectra of derivatives $\mathrm{B}_{12}$-JR1-3 are shown in Figure 3 (full spectra of all molecules are found in ESI, Figures S1-S11). NMR was used with other techniques to assess the successful synthesis of the molecules. As evident in Figure 3, the aromatic region shows an increasing number of peaks after each modification which are related and consistent with the addition of the alkynylated linker and the CQ drug on cobalamin (see also Figures S4-S8 in ESI). As expected, with respect to free vitamin $\mathrm{B}_{12}$, most affected are the Co-bound dimethylbenzimidazole peaks and the ribose signals (in the 4.5-5 ppm regions, see Figures S4-S8 in ESI) which suffer an upfield shift after each cobalamin modification. From a stability point of view, all water-soluble 
compounds appeared photo stable in solution for at least seven days. Alongside the preparation of the vitamin $\mathrm{B}_{12}$ derivatives, ethynylphenyl-triazolyl-chloroquine and imidazolopiperazine drugs (JR1-3 and SN1, Figure 2) were synthetized separately from the reaction of N3-CQ or N3-SN1 with either 1,4-diethynylbenzene (JR1, SN1) or 1,4-diethynyl-2-fluorobenzene (JR2 and JR3). The compounds were purified via HPLC and isolated as TFA salts. Of the series of compounds described above, we were able to obtain single crystals suitable for X-ray analysis of the B12-F2 precursor and the JR1 compound (namely, 7-chloro- $N$-(2-(4-(4-ethynylphenyl)-1H-1,2,3-triazol-1-yl)ethyl)quinolin-4-amine, Figure 3). B12-F2 crystalized in the orthorhombic space group $\mathrm{P} 2{ }_{1} 2_{1} 2_{1}$ (common for Cbl derivatives). Interestingly, the 1,4-diethynyl-2-fluorobenzene unit is found in two different conformations in the crystal structure. In both conformations, the $\mathrm{Co}-\mathrm{C} \equiv \mathrm{C}$ angle is bent $\left(167.92^{\circ}(2)\right.$ and $\left.173.27(3)^{\circ}\right)$ and the triple bond length is longer than in organic alkynes (1.211 (16) $\AA$ and 1.192 (17) $\AA$ respectively), which is consistent with previously reported acetylide cobalamins [30,32]. Compound JR1 crystalized in the P-1triclinic space group and it is also shown in Figure 3.

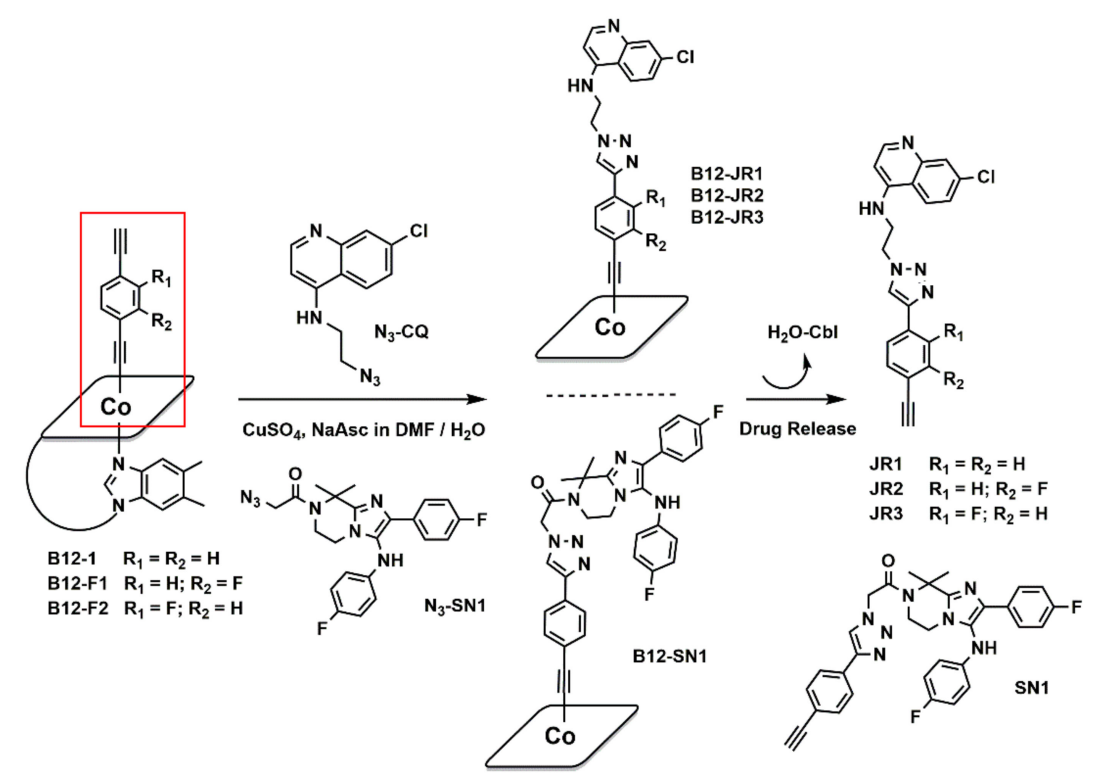

Figure 2. General synthetic scheme for the synthesis of derivatives $B_{12}-J R 1-J R 3$ and $B_{12}-S N 1$.

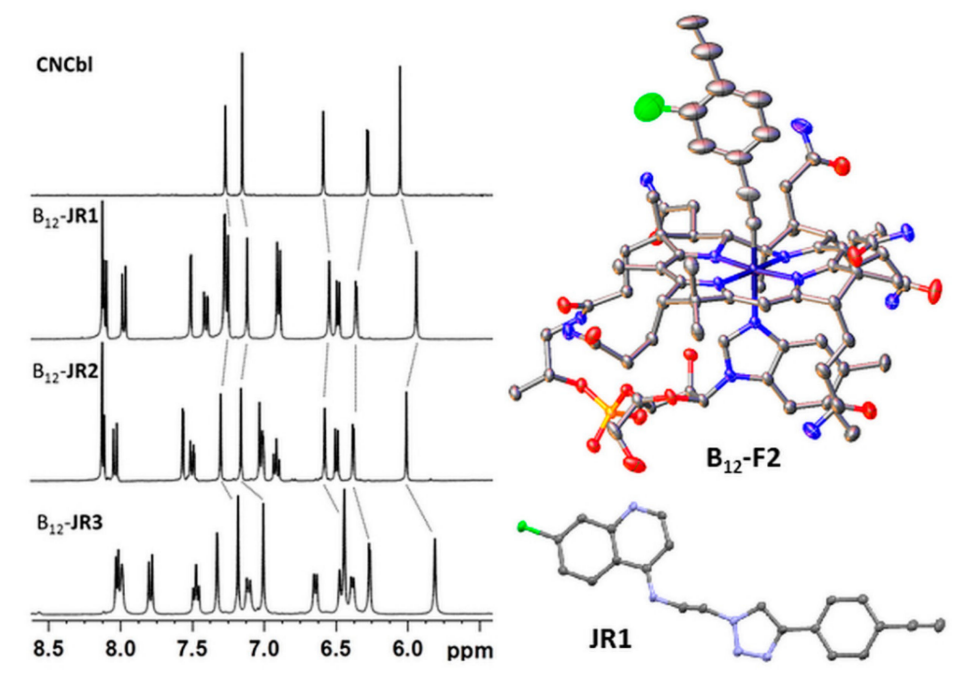

Figure 3. Left, aromatic region of the ${ }^{1} \mathrm{H}-\mathrm{NMR}$ spectra $\left(\mathrm{D}_{2} \mathrm{O}, 500 \mathrm{MHz}\right)$ of $\mathrm{CN}-\mathrm{Cbl}$ and of the derivatives $\mathrm{B}_{12}$-JR1 to -JR3. Right, crystal structure of compound $\mathrm{B}_{12}-\mathrm{F} 2$ and of JR1 (thermal ellipsoids are shown at the $50 \%$ probability). 


\subsection{In Vitro Bio-Distribution and Antiplasmodial Activity}

Given that the pathogenesis of the disease is based on the rosetting phenomenon [33], occurring during the life cycle of the P. falciparum in red blood cells (RBCs) promoting the binding of parasitized RBCs to healthy ones, our conceptual design pivots on the possibility that when attached to the cobalamin scaffold antimalarial drugs can be delivered to both erythrocytes and hepatocytes and intracellularly released following the natural $\mathrm{Cbl}$ pathway. We therefore needed to establish if the modified vitamins could still accumulate within red blood cells to some extent. To this end, $\mathrm{B}_{12}$-JR1 was modified at the sugar moiety with a fluorescent dye in order to track its bio-distribution both in vitro and in vivo [34]. As shown in the synthetic protocol illustrated in Figure 4, the 5'-OH group of the Cbl ribose was activated with 1,1'-carbonyl-di-(1,2,4-triazole) (CDT) and then reacted with an amine-terminated Polyethylene glycol (PEG) chain to promote amide bond formation [34]. This intermediate was then reacted with 5-carboxy-tetramethyl-rhodamine succinimidyl ester (NHS-Rhodamine) to yield the fluorescent $\mathrm{B}_{12}$-JR1-CBC molecule. $\mathrm{B}_{12}$-JR1-CBC was then incubated within full canine blood at $37^{\circ} \mathrm{C}$ for $24 \mathrm{~h}$ in dark. After this period of time, red fluorescence was observed within erythrocytes in the full blood smear of the blood sample (Figure 4 C-D), and we could determine that between 11-13\% of the compound associates with washed erythrocytes after $24 \mathrm{~h}$ incubation (Figure S21).

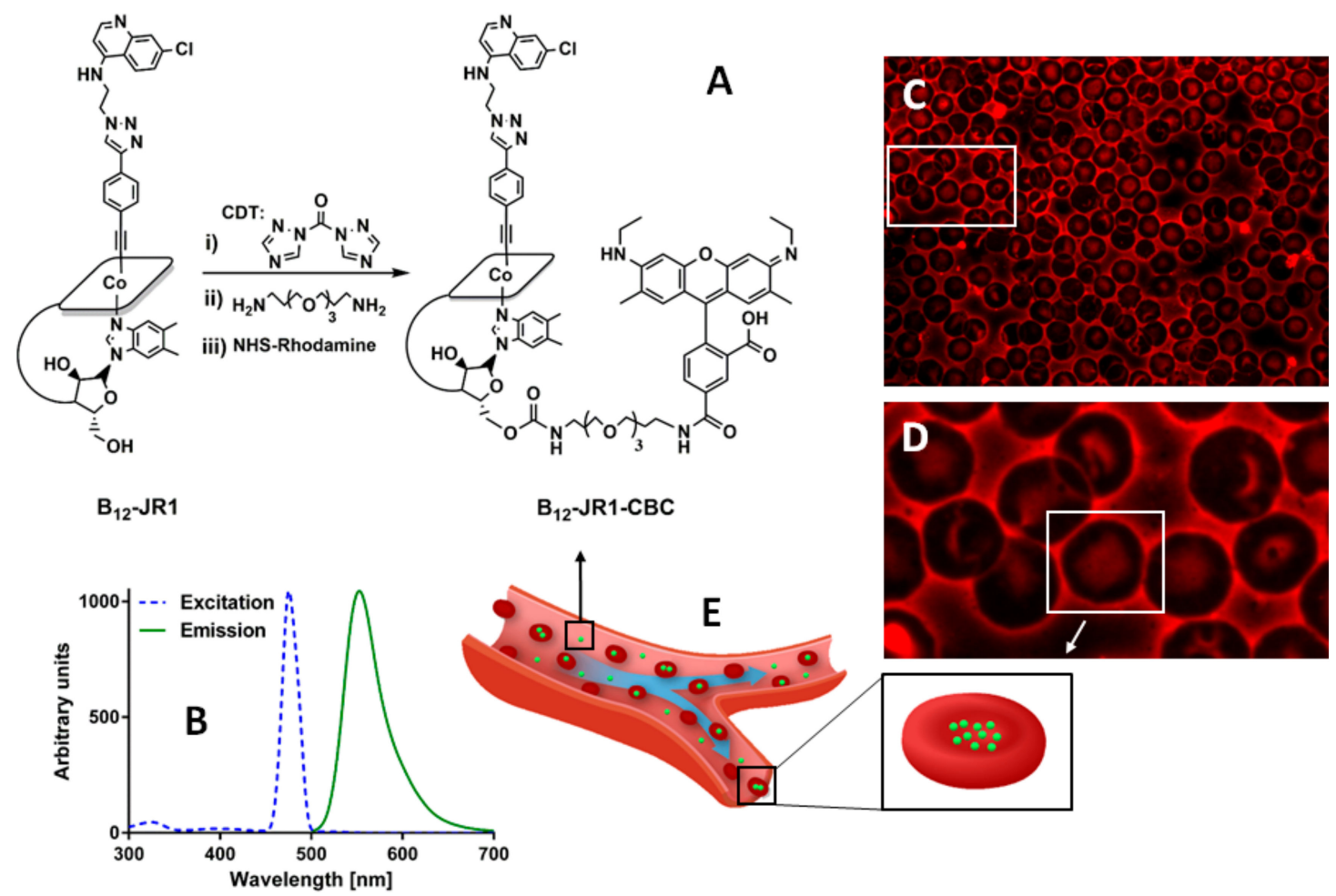

Figure 4. (A) Reaction steps leading to the synthesis of the green emitting $\mathrm{B}_{12}$-JR1-CBC. Conditions: (i) CDT, 12 h, DMSO; (ii) PEG, 12 h, anhydrous DMF; (iii) NHS-rhodamine, $12 \mathrm{~h}$, TEA, anhydrous DMF. (B) Normalized excitation and emission profile of $\mathrm{B}_{12}-\mathrm{JR} 1-\mathrm{CBC}$ in a 1:1 $\mathrm{H}_{2} \mathrm{O} / \mathrm{MeOH}$ solution. (C,D) Fluorescent microscope images of erythrocytes within full canine blood smear incubated with $\mathrm{B}_{12}$-JR1-CBC at $37{ }^{\circ} \mathrm{C}$ (GFP filter; $100 \times$ magnification). (E) Conceptual drawing of $\mathrm{B}_{12}$-JR1-CBC accumulation within erythrocytes. Note: as a full blood smear was made, fluorescence around red blood cells is due to serum and/or burst erythrocytes.

Having established the intracellular erythrocyte accumulation of $\mathrm{B}_{12}$-JR1-CBC, the $\mathrm{B}_{12}$ complexes B 12 -JR1-3, -SN1 and their corresponding 4-(4-ethynylphenyl)-triazole drugs JR1-3 and SN1 were tested for their antiplasmodial activity against the erythrocyte stage of Plasmodium falciparum. All the compounds were screened against the NF54 CQS (chloroquine-sensitive) strain of P. falciparum and 
the multidrug-resistant P. falciparum Thailand K1 strain CQR (chloroquine-resistant) isolate. Table 1 presents the data obtained from this study.

Table 1. Antiplasmodial activity of molecules against the chloroquine-sensitive (CQS) NF54 and chloroquine-resistant (CQR) K1 strains of Plasmodium falciparum.

\begin{tabular}{|c|c|c|c|}
\hline Compound & NF54 $\mathrm{IC}_{50} \pm \mathrm{SD}(\mu \mathrm{M})$ & $\mathrm{K} 1 \mathrm{IC}_{50} \pm \mathrm{SD}(\mu \mathrm{M})$ & Resistance Index (RI) ${ }^{a}$ \\
\hline JR1 & $0.14 \pm 0.01$ & $0.18 \pm 0.02$ & 1.3 \\
\hline $\mathrm{JR} 2$ & $0.15 \pm 0.01$ & $0.16 \pm 0.01$ & 1.1 \\
\hline JR3 & $0.19 \pm 0.02$ & $0.21 \pm 0.02$ & 1.1 \\
\hline $\mathrm{B}_{12}-\mathrm{JR} 1$ & $6.27 \pm 0.37$ & $9.18 \pm 0.85$ & 1.5 \\
\hline $\mathrm{B}_{12}$-JR2 & $4.73 \pm 0.32$ & $6.02 \pm 0.71$ & 1.3 \\
\hline $\mathrm{B}_{12}-\mathrm{JR} 3$ & $9.68 \pm 0.73$ & $>15$ & $>1.6$ \\
\hline SN1 & na ${ }^{b}$ & $\mathrm{nd}^{\mathrm{c}}$ & nd \\
\hline $\mathrm{B}_{12}-\mathrm{SN1}$ & na & nd & nd \\
\hline CQ & $0.013 \pm 0.001$ & $0.40 \pm 0.04$ & 30.8 \\
\hline
\end{tabular}

${ }^{\mathrm{a}} \mathrm{RI}$ (resistance index): $\mathrm{IC}_{50}(\mathrm{CQR}) / \mathrm{IC}_{50}(\mathrm{CQS}){ }^{\mathrm{b}}$ Not active at the tested concentration; ${ }^{\mathrm{c}}$ Not determined.

Triazole-containing quinoline JR1, JR2 and JR3 showed good activity in the sensitive strain, while the imidazolopiperazine derivatives $\mathbf{S N 1}$ and $\mathrm{B}_{12}-\mathrm{SN} 1$ were inactive. $\mathrm{B}_{12}-\mathrm{JR}-\mathbf{3}$ exhibited moderate activity in the NF54 strain of P. falciparum with $\mathrm{IC}_{50}$ values ca. 30-40 times higher than those of their corresponding drugs JR1-3. The decrease in activity of the vitamin $\mathrm{B}_{12}$ derivatives, compared to their corresponding free drugs, indicates that there are no synergistic effects between the molecular components (i.e., $B_{12}$ and JR\#). Indeed, the relatively low in vitro activity of the $B_{12}$ derivatives could be attributed to low accumulation of these complexes in the digestive vacuole (DV) of the parasite as some cobalamin compounds are less likely to accumulate in DV due to limited $\mathrm{pH}$ trapping [20]. Nevertheless, JR1-3, $B_{12}-\mathbf{J R} 1$ and $B_{12}-J R 2$ are equally active against the chloroquine-resistant (CQR) K1 strain of $P$. falciparum, with resistance indices very close to unity. In terms of their cytotoxicity, molecules $B_{12}$-JR1-3 showed moderate activity against human lung fibroblast MRC5 $\left(\mathrm{IC}_{50}>70 \mu \mathrm{M}\right)$ which brings their selectivity index to the value of 10 and higher. Furthermore, $\mathrm{B}_{12}-\mathrm{JR} 1$ was screened against the Chinese Hamster Ovarian (CHO) cell-line at a concentration ca. 400-fold its NF54 $\mathrm{IC}_{50}$ value and was found not to be toxic against mammalian cells at this dose. This confirms that these $B_{12}$ complexes are selective towards the malaria parasite and because the compounds retain their activity in the resistant strain show no cross-resistance.

\subsection{Drugs Interaction with Monomeric Ferriprotoporphyrin IX (PPIX)}

Chloroquine (CQ) exerts its antimalarial function by inhibiting hemozoin formation during the critical ferriheme detoxification process of the Plasmodium parasite [35-39]. The molecule acts either by: (a) directly complexing monomeric PPIX preventing its incorporation into the growing hemozoin crystals [36,40-42], (b) capping the hemozoin crystal [43,44], (c) binding to PPIX via $\pi-\pi$ interactions between the its aromatic ring and the porphyrin ring [45,46], (d) shifting the haematin/ $\mu$-oxo PPIX dimer equilibrium [40], or (e) docking onto the fastest growing crystal face [47]. To obtain an insight into the possible mode of action of the 4-(4-ethynylphenyl)-triazole functionalized drugs, we decided to study their interaction with strictly monomeric ferriprotoporphyrin IX via the procedure established by Egan et al. [48,49].

Accordingly, we performed spectrophotometric titrations of the drugs into a solution of PPIX and monitored the absorbance of the Soret band at $402 \mathrm{~nm}$. Figure 5 shows the spectral changes observed in these experiments. The decrease in absorbance of the Soret band is either indicative of a drug-induced aggregation of PPIX, formation of $\pi-\pi$ (donor acceptor) complexes or the changes reflect drug binding to PPIX [48,49]. Our molecular design offers at least four binding possibilities to ferriheme, but we were able to establish via DFT calculations that only the quinoline and the central triazole 
nitrogens are free of steric hindrance to support PPIX coordination (Figure S12 and S13). However, analysis of the spectrophotometric changes revealed that: a) none of our drugs are likely forming a 1:1 or 2:1 binding complex with PPIX as data do not fit the models of Egan et al.; b) the changes are dissimilar from those observed upon PPIX aggregation in aqueous solution [48]; c) the end-point spectra, after addition of a large excess of drugs, are identical to that of the $\mu$-oxo dimer previously reported (Figure 5C) [50]. We conclude, therefore, that JR1-3 might exert their antiplasmodial activity by promoting ferriprotoporphyrin $\mu$-oxo dimer formation, thereby shifting the haematin/ $\mu$-oxo PPIX dimer equilibrium [40].
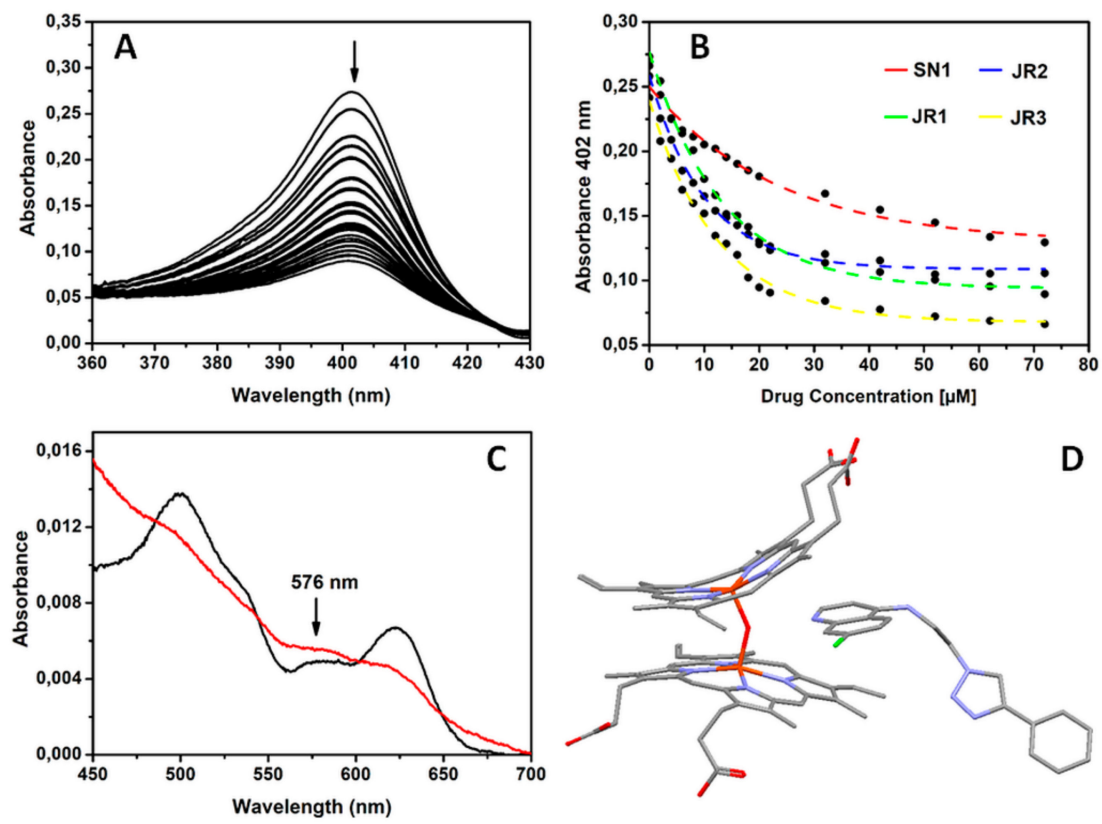

Figure 5. (A) Spectroscopic change observed in the Soret band of PPIX when it is titrated with drugs presented in this study. (B) Variation in absorbance of PPIX at $402 \mathrm{~nm}$ as a function of drug concentration. (C) Visible spectra of PPIX in 40\% aqueous DMSO, pH 7.5 before (black line) and after addition of excess drug (red line). The spectrum of the latter is identical to that of the $\mu$-oxo dimer previously reported. Note the peak maximum at $576 \mathrm{~nm}$. (D) Density Functional Theory (DFT) optimized structure (gas-phase) of the interaction of a protonated 4-(4-ethynylphenyl)-triazole functionalized quinoline drug model with ferriprotoporphyrin IX $\mu$-oxo dimer.

\subsection{In Vivo Toxicity and Bio-Distribution}

Based on the antiplasmodial activity and in vitro cytotoxicity results, $\mathrm{B}_{12}-\mathbf{J R} \mathbf{1}$ was selected for further toxicity and distribution assessment in the zebrafish (Danio rerio) model, which proved a useful high-throughput model for determination of the acute toxicity in drug development efforts [51]. Toxicity assessment performed in the zebrafish model (nontransgenic, wild type embryos) during a period from 6 to $120 \mathrm{~h}$ post fertilization (hpf) showed that vitamin $\mathrm{B}_{12}$ (data not shown) and $\mathrm{B}_{12}-\mathrm{JR} \mathbf{1}$ are neither toxic (Figure 6A) nor cardiotoxic (Figure 6B) at the doses up to $150 \mu \mathrm{M}$. On the other hand, the CBC-labelled molecule $\left(B_{12}-J R 1-C B C\right)$ caused the appearance of pericardial edema and the whole-body edema/disintegration in $25 \%$ of embryos already at a dose of $25 \mu \mathrm{M}$ (the same side effects were observed at $50 \mu \mathrm{M}$, in almost $100 \%$ of treated embryos). Notably, the toxicity of $\mathrm{B}_{12}-\mathrm{JR} \mathbf{1}$ appeared to be markedly higher in vitro than in vivo ( $\mathrm{IC}_{50}$ of $70 \mu \mathrm{M}$ vs $\mathrm{LC}_{50}>150 \mu \mathrm{M}$, respectively). According to the antiplasmodial activity and the in vivo toxicity results, $\mathrm{B}_{12}-\mathrm{JR} \mathbf{1}$ has a large therapeutic window-higher than 24 for the NF54 strain (CQ-sensitive) and 16 for the K1 strain (CQ-resistant) of P. falciparum (Table 2). 

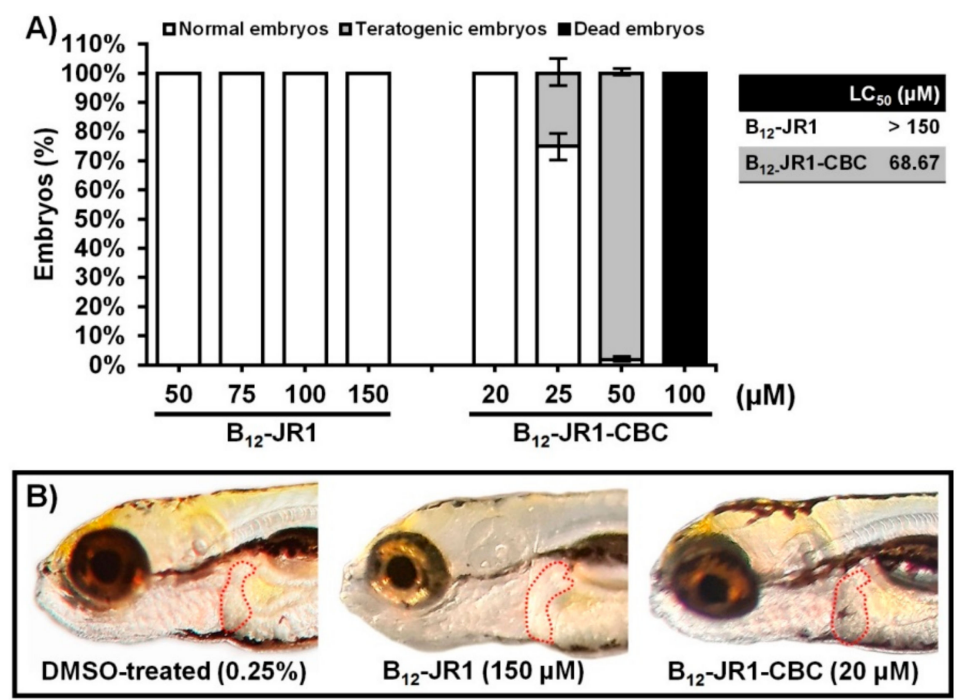

Figure 6. Toxicity evaluation of $\mathrm{B}_{12}-\mathrm{JR} 1$ and $\mathrm{B}_{12}-\mathrm{JR} 1-\mathrm{CBC}$ in the zebrafish model over a period from 6 to $120 \mathrm{hpf}$, expressed as the $\mathrm{LC}_{50}$ values. Shown are data relative to (A) embryos survival/teratogenicity and (B) cardiotoxicity. The liver is outlined with a dashed line.

Table 2. Therapeutic windows of $\mathrm{B}_{12}-\mathrm{JR} 1$ for NF54 strain (CQ-sensitive) and K1 strain (CQ-resistant) of P. falciparum.

\begin{tabular}{|c|c|c|c|c|c|}
\hline & \multicolumn{2}{|c|}{$\mathrm{IC}_{50}(\mu \mathrm{M})^{\mathrm{a}}$} & \multirow[t]{2}{*}{$\mathrm{LC}_{50}(\mu \mathrm{M})^{\mathrm{b}}$} & \multicolumn{2}{|c|}{$\mathrm{Ti}\left(\mathrm{LC}_{50} / \mathrm{IC}_{50}\right)$} \\
\hline & NF54 & $\mathrm{K} 1$ & & NF54 & K1 \\
\hline $\mathrm{B}_{12}$-JR1 & 6.3 & 9.2 & $>150$ & $>23.9$ & $>16.3$ \\
\hline
\end{tabular}

To determine the distribution and the accumulation of $\mathrm{B}_{12}-\mathrm{JR} 1$ and $\mathrm{B}_{12}-\mathrm{JR} 1-\mathrm{CBC}$ through inner organs, transgenic $T g(f a b p 10: E G F P)$ zebrafish embryos with enhanced green fluorescent protein (EGFP)-labelled liver were exposed to the tested compounds in a period from 106-120 hpf (the developmental stage when the liver is highly vascularized and metabolically active). The results showed the preferential accumulation of both compounds in the liver of treated fish when applied in the water containing the embryos (Figure S23), as well as in the intestine due to the compounds absorption through mouth and skin (Figure 7, Panel 1). Longer exposure (from 72-120 hpf) of zebrafish embryos to the tested molecules resulted in higher drug accumulation in the liver, as evaluated by the fluorescence intensity (Figure S23). Moreover, when $B_{12}$-JR1 and $B_{12}$-JR1-CBC were applied parenteral by the microinjection into the blood circulation, the compounds were solely detected in the liver of injected embryos, confirming thus their preferential accumulation in this organ. Importantly, after this period of exposure the compounds did not affect the liver development. Because liver toxicity presents one of the most common drawbacks of the drugs approved for the human use, the drugs synthesized in this study were examined for the possible hepatotoxicity in vivo. The transgenic $T g(f a b p$ :EGFP) zebrafish embryos exposed at $72 \mathrm{hpf}$ (a stage when the liver is becoming vascularized and performing metabolic transformation of the absorbed compounds) to the synthesized drugs were evaluated for the liver colour (a possible necrosis sign), size, fluorescence and the liver area index (the body area/liver area ratio). These are all parameters commonly used for hepatotoxicity evaluation and to follow the effect of applied therapies on the liver function. 

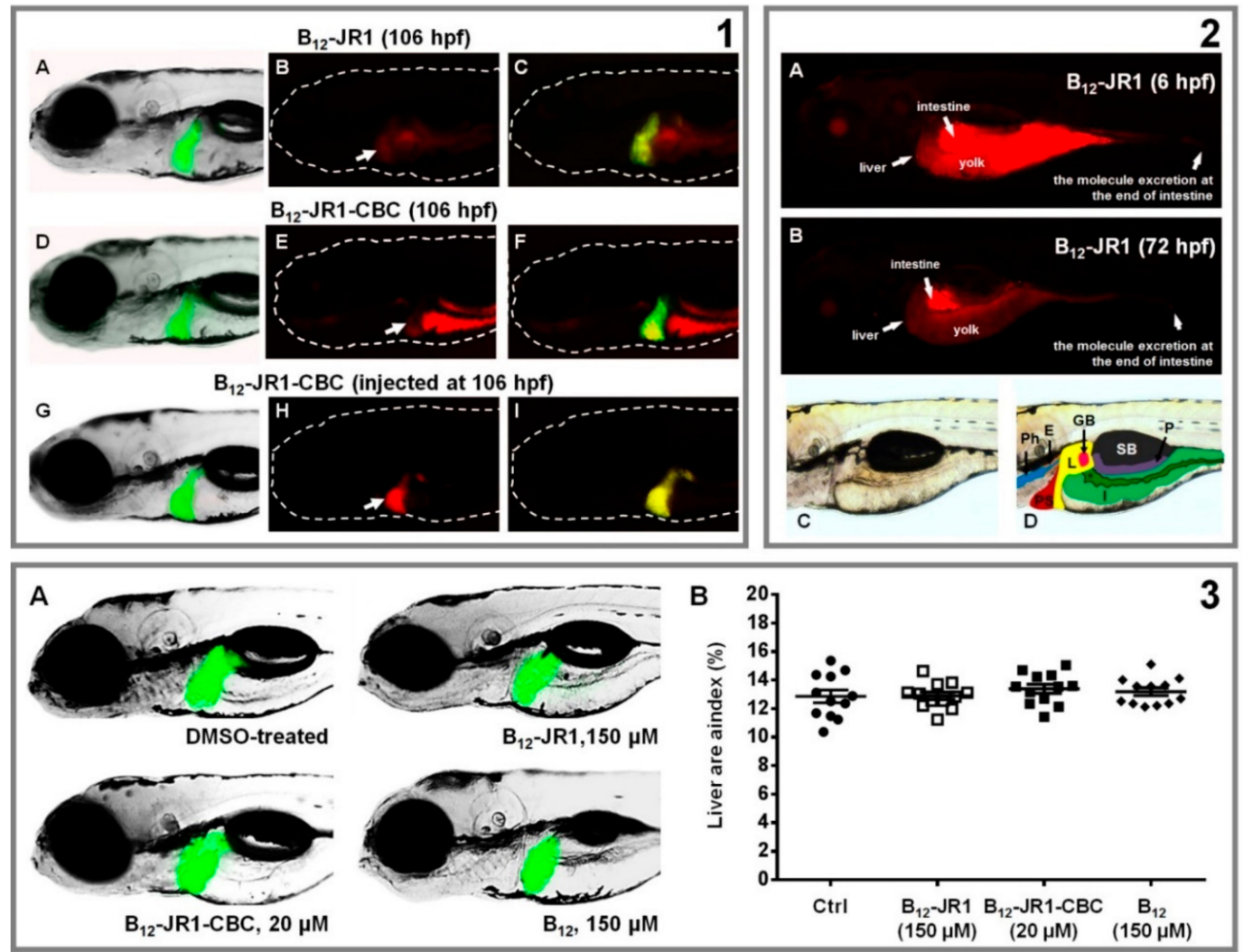

Figure 7. Bio-distribution and toxicity evaluation of $B_{12}-J R 1$ and $B_{12}-J R 1-C B C$ in the 120-hpf old transgenic $T g(f a b p 10: E G F P)$ zebrafish embryo with fluorescently labelled liver. Panel 1 (top left). Top: accumulation of $\mathrm{B}_{12}$-JR1 $(150 \mu \mathrm{M})$ in the liver applied at $106 \mathrm{hpf}$ in the embryo water. (A) Embryo imaged by a fluorescent microscope with a filter enabling only EGFP-labelled liver visualization. (B) Embryo imaged with a filter enabling $B_{12}$-JR1 visualization, but not EGFP-labelled liver. (C) Merged images A and B. Middle: accumulation of $B_{12}-J R 1-C B C(20 \mu \mathrm{M})$ in the liver applied at $106 \mathrm{hpf}$ in the embryo water. (D) Embryo imaged upon a filter enabling only EGFP-labelled liver visualization. (E) Embryo imaged with a filter enabling only $\mathrm{B}_{12}-\mathrm{JR} \mathbf{1}$ visualization, and (F) merged $\mathrm{Tg}$ (fabp10:EGFP) and $\mathrm{B}_{12}$-JR1-CBC fluorescent signals in the same embryo. Bottom: an accumulation of $\mathrm{B}_{12}$-JR1-CBC (47.8 $\mu \mathrm{g}$ per an embryo, corresponding to $20 \mu \mathrm{M}$ dose) in the liver microinjected (parenteral use) into embryo's circulation at $106 \mathrm{hpf}$. Arrows in the panel 1 indicate the liver position within embryos body. Panel 2 (top right): distribution of $\mathrm{B}_{12}$-JR1 $(150 \mu \mathrm{M})$ within the 120-hpf old embryos when applied at $6 \mathrm{hpf}$ (the liver-free stage, A) or $72 \mathrm{hpf}$ (the stage with functional liver, B). Lateral views (C and D) of the 120-hpf embryo with an overlay. Overlay outlines the pharynx (Ph), esophagus (E), liver $(\mathrm{L})$, gallbladder $(\mathrm{G})$, pancreas $(\mathrm{P})$, swimmbladder $(\mathrm{SB})$, and intestine $(\mathrm{I}) .{ }^{*}$ marks intestinal lumen. Panel 3 (bottom). Hepatotoxicity evaluation in the transgenic $\operatorname{Tg}(f a b p 10$ :EGFP) zebrafish embryos with EGFP-labelled liver after the embryos exposure to the tested compounds in a period from 72-120 hpf (A). The liver area index was assessed in 120-h old zebrafish embryos (B) and indicated no changes in the treated groups compared to the DMSO-treated (control) one $(n=15)$.

The results show that both compounds, applied at the $150 \mu \mathrm{M}$ for $\mathrm{B}_{12}$-JR1 and $20 \mu \mathrm{M}$ for $\mathrm{B}_{12}$-JR1-CBC, caused no changes in the liver size and fluorescence (Figure 7, Panel 3), and did not affect the liver area index. In addition, liver colour and yolk consumption in the treated fish, as additional specific phenotypic endpoints of hepatotoxicity, did not change in comparison to that of the control embryos (Figure 7, Panel 2), even when the embryos were exposed earlier at the 6 hpf stage (Figure 6B). Overall, the results indicate that $B_{12}-J R 1$ is not hepatotoxic, at least, at a dose 16-24 higher than the one active against Plasmodium strains. Taken together, the results indicate that $\mathrm{B}_{12}-\mathbf{J R} \mathbf{1}$ and $\mathrm{B}_{12}-\mathbf{J R} \mathbf{1}-\mathbf{C B C}$ indeed accumulate in the liver, and cause no hepatotoxicity, no cardiotoxicity or developmental toxicity 
at concentrations efficient against $P$. falciparum. This is of particular relevance in the therapy against the CQ-resistant malarial strains, since chloroquine, the most frequently used antiplasmodial drug, is very hepatotoxic already at $30 \mu \mathrm{M}$ [52], while $\mathrm{B}_{12}-\mathrm{JR} 1$ is not at $150 \mu \mathrm{M}$.

\section{Materials and Methods}

\subsection{General Experimental Details}

All chemicals were purchased from Sigma-Aldrich (St Louis, MO, USA) and used without further purification. HPLC analyses were performed on a Merck-Hitachi L7000 (Hitachi, Ltd., Tokyo, Japan). The analytical separations were conducted on a Macherey-Nagel Nucleodur PolarTec column (Macherey-Nagel AG, Oensingen, Switzerland, $5 \mu \mathrm{m}$ particle size, $110 \AA$ pore size, $250 \times 3 \mathrm{~mm}$ ). The preparative separations were conducted on a Macherey-Nagel Nucleodur C18 HTec column (Macherey-Nagel AG, Oensingen, Switzerland, $5 \mu \mathrm{m}$ particle size, $110 \AA$ pore size, $250 \times 21 \mathrm{~mm}$ ). HPLC solvents were for the system 1: aqueous trifluoroacetic acid $0.1 \%$ (A) and THF (B). HPLC solvents were for the system 2: aqueous trifluoroacetic acid $0.1 \%$ (A) and methanol (B). Using system 1, the compounds were separated using the following gradient: 0-5 min (75\% solvent A), 5-35 (75\% solvent A $\rightarrow$ 35\% solvent A), 35-45 min (100\% solvent B). Using system 2, the compounds were separated using the following gradient: $0-5 \mathrm{~min}$ (75\% solvent A), 5-35 (75\% solvent $\mathrm{A} \rightarrow 0 \%$ solvent $\mathrm{A}), 35-45 \mathrm{~min}(100 \%$ solvent $\mathrm{B})$. The flow rate was set to $0.5 \mathrm{~mL} / \mathrm{min}$ for analytical separations and $5 \mathrm{~mL} / \mathrm{min}$ for the preparative ones. The eluting bands were detected at $320 \mathrm{~nm}$. The preparative plates used for the separation of the compounds 7-chloro-N-(2-(4-(4-ethynyl-3-fluorophenyl)-1H-1,2,3-triazol-1-yl)ethyl)quinolin-4-amine (JR2) and 7-chloro-N-(2-(4-(4-ethynyl-2-fluorophenyl)-1H-1,2,3-triazol-1-yl)ethyl)quinolin-4-amine (JR3) were purchased from Sigma-Aldrich $(20 \mathrm{~cm} \times 20 \mathrm{~cm}, 2 \mathrm{~mm})$. NMR analyses were recorded on a Bruker Avance III $500 \mathrm{MHz}$. The corresponding ${ }^{1} \mathrm{H}$ and ${ }^{13} \mathrm{C}$ chemical shifts are reported relative to residual solvent protons and carbons.

\subsection{Instrumentation}

HPLC analyses were performed on a Merck-Hitachi L7000 (Hitachi, Ltd., Tokyo, Japan). High resolution ESI-MS was performed on a Bruker FTMS 4.7-T Apex II (Bruker Daltonics GmbH, Fällanden, Switzerland). NMR spectra were recorded on a Bruker Avance III $500 \mathrm{MHz}$ (Bruker Daltonics GmbH, Fällanden, Switzerland). UV/Vis spectra were recorded on a Jasco V-730 (JASCO Deutschland GmbH, Pfungstadt, Germany) and the emission on a spectrofluorometer FS5 (Edinburgh Instruments Ltd., Livingston, UK). Titration experiments were performed as described by Egan et al. [49]. with the only exception that PBS (Phosphate-Buffered Saline) (1X, pH 7.4) was used instead of the $N$-[2-hydroxethyl]piperazine- $N^{\prime}$-[2-ethane sulphonate] (HEPES) buffer. Crystallographic data were recorded on a SuperNova, Dual, $\mathrm{Cu}$ at zero, AtlasS2 diffractometer (Agilent Technologies XRD Products, Santa Clara, CA, USA). For biological studies, the extent of MTT reduction was measured spectrophotometrically via a Tecan Infinite 200 Pro multiplate reader (Tecan Group Ltd., Männedorf, Switzerland). Microscopy and fluorescent images were recorded with an inverted microscope (CKX41; Olympus, Tokyo, Japan) and a fluorescent microscope (Olympus BX51, Applied Imaging Corp., San Jose, CA, USA) respectively.

\subsection{Computational Details}

Geometry optimizations as well as frequency calculations (gas phase), were performed at the Density Functional level of theory with the Gaussian09 program package (AMD64, Gaussian Inc., Wallingford, CT, USA) using the hybrid B3LYP [53] or M06 [54,55] functional in conjunction with the LanL2DZ basis set [56-58]. Pure basis functions (5d, 7f) were used in all calculations. Geometries were optimized without symmetry restrictions. The nature of the stationary points was checked by computing vibrational frequencies in order to verify true minima. 


\subsection{General Synthesis Procedures}

Synthesis procedures for 7-chloro- $N$-(2-(4-(4-ethynylphenyl)-1H-1,2,3-triazol-1-yl)ethyl)quinolin4-amine (compound JR1), a mixture of $\mathrm{N}$-(2-azidoethyl)-7-chloroquinolin-4-amine ( $\left.\mathrm{N}_{3}-\mathrm{CQ}\right)(100 \mathrm{mg}$, $0.4 \mathrm{mmol}, 1$ eq.), 1,4-diethynylbenzene $(60.5 \mathrm{mg}, 0.5 \mathrm{mmol}, 1.2$ eq.) and tris(benzyltriazolylmethyl)amine (TBTA, $2 \mathrm{mg}, 0,004 \mathrm{mmol}, 1 \mathrm{~mol}-\%)$ was dissolved in DMF $(0.7 \mathrm{~mL})$. To this solution was added a water mixture $(0.3 \mathrm{~mL})$ of $\mathrm{CuSO}_{4} \cdot 5 \mathrm{H}_{2} \mathrm{O}(1 \mathrm{mg}, 0,004 \mathrm{mmol}, 1 \mathrm{~mol}-\%)$ and sodium ascorbate $(8 \mathrm{mg}, 0,04 \mathrm{mmol}$, 0,1 eq.). The compounds were reacted overnight with stirring at room temperature. The compounds 7-chloro- $N$-(2-(4-(4-ethynyl-3-fluorophenyl)-1H-1,2,3-triazol-1-yl)ethyl)quinolin-4-amine (JR2) and 7-chloro- $N$-(2-(4-(4-ethynyl-2-fluorophenyl)-1H-1,2,3-triazol-1-yl)ethyl)quinolin-4-amine (JR3) were prepared similarly by replacing the 1,4-diethynylbenzene with 1,4-diethynyl-2-fluorobenzene (72 $\mathrm{mg}$, $0.5 \mathrm{mmol}, 1.2 \mathrm{eq}$.). Following the reaction, the solution containing JR1 was filtered and purified by HPLC (system 2). The crude reaction containing both JR2 and JR3 compounds was also filtered and the filtrate freeze-dried. The remaining solid was redissolved in the minimal amount of DMF $(0.2 \mathrm{~mL})$ and completed with $\mathrm{DCM} / \mathrm{MeOH}(0.4 \mathrm{~mL}, 9: 1)$. The isomers were separated on a preparative TLC plate using DCM/MeOH (9:1) as eluent.

7-Chloro-N-(2-(4-(4-ethynylphenyl)-1H-1,2,3-triazol-1-yl)ethyl)quinolin-4-amine (JR1): yield $123 \mathrm{mg}$ (0.033 mmol, 83\%). ${ }^{1} \mathrm{H}$ NMR (500 MHz, DMF-[d7]): $\delta=9.68(\mathrm{t}, J=5.6 \mathrm{~Hz}, 1 \mathrm{H}), 8.82(\mathrm{~s}, 1 \mathrm{H}), 8.70(\mathrm{~d}$, $J=6.9 \mathrm{~Hz}, 1 \mathrm{H}), 8.60(\mathrm{~d}, J=9.0 \mathrm{~Hz}, 1 \mathrm{H}), 8.23(\mathrm{~d}, J=2.0 \mathrm{~Hz}, 1 \mathrm{H}), 8.03(\mathrm{~s}, 1 \mathrm{H}), 7.89(\mathrm{~d}, J=8.45 \mathrm{~Hz}, 2 \mathrm{H})$, $7.70(\mathrm{dd}, J=7.76 \mathrm{~Hz}, 1 \mathrm{H}), 7.58(\mathrm{dd}, J=8.35 \mathrm{~Hz}, 1 \mathrm{H}), 7.16(\mathrm{~d}, J=7 \mathrm{~Hz}, 1 \mathrm{H}), 4.97(\mathrm{t}, J=5.7 \mathrm{~Hz}, 2 \mathrm{H}), 4.31$ $(\mathrm{dd}, J=5.3,5.8 \mathrm{~Hz}, 2 \mathrm{H}), 4.20$ (s, $1 \mathrm{H}) \mathrm{ppm} ;{ }^{13} \mathrm{C} \mathrm{NMR}\left(125 \mathrm{MHz}, \mathrm{CDCl}_{3}-[\mathrm{d} 1]\right): \delta=165.4,157.1,146.4$, 145.4, 141.1, 139.6, 135.8, 135.3, 128.4, 126.3, 124.5, 122.4, 121.6, 117.4, 113.0, 110.5, 100.1, 86.9, 77.8, 49.5, 44.5 ppm; HR-ESI-MS (ESI $\left.{ }^{+}\right):[\mathrm{M}+\mathrm{H}]^{+}=374.1176$, calculated for $\mathrm{C}_{21} \mathrm{H}_{17} \mathrm{~N}_{5} \mathrm{Cl}_{1}=374.1167$.

7-Chloro-N-(2-(4-(4-ethynyl-3-fluorophenyl)-1H-1,2,3-triazol-1-yl)ethyl)quinolin-4-amine (JR2): yield $67 \mathrm{mg}(0.017 \mathrm{mmol}, 43 \%) .{ }^{1} \mathrm{H}$ NMR $(500 \mathrm{MHz}, \mathrm{DMF}-[\mathrm{d} 7]): \delta=9.59(\mathrm{t}, J=5.86 \mathrm{~Hz}, 1 \mathrm{H}), 8.88(\mathrm{~s}, 1 \mathrm{H}), 8.74$ $(\mathrm{d}, J=6.9 \mathrm{~Hz}, 1 \mathrm{H}), 8.56(\mathrm{~d}, J=9.0 \mathrm{~Hz}, 1 \mathrm{H}), 8.19(\mathrm{~d}, J=2.0 \mathrm{~Hz}, 1 \mathrm{H}), 7.79(\mathrm{dd}, J=2.0,9.0 \mathrm{~Hz}, 1 \mathrm{H}), 7.75(\mathrm{t}$, $J=1.45 \mathrm{~Hz}, 1 \mathrm{H}), 7.73(\mathrm{dd}, J=1.45,4.5 \mathrm{~Hz}, 1 \mathrm{H}), 7.66(\mathrm{t}, J=7.7 \mathrm{~Hz}, 1 \mathrm{H}), 7.16(\mathrm{~d}, J=6.8 \mathrm{~Hz}, 1 \mathrm{H}), 4.98$ $(\mathrm{t}, J=6.15 \mathrm{~Hz}, 2 \mathrm{H}), 4.54(\mathrm{~s}, 1 \mathrm{H}), 4.31(\mathrm{dd}, J=5.5,5.8 \mathrm{~Hz}, 2 \mathrm{H}) \mathrm{ppm} ;{ }^{13} \mathrm{C} \mathrm{NMR}\left(125 \mathrm{MHz}, \mathrm{CDCl}_{3}-[\mathrm{d} 1]\right)$ : $\delta=156.3,146.5,144.3,140.0,138.8,132.8(2 \mathrm{C}), 132.0,127.5,125.6$ (3C), 123.0, 121.8, 120.4, 116.5, 99.3, 83.7, 80.6, 48.5, 43.8 ppm; HR-ESI-MS (ESI ${ }^{+}$): $[\mathrm{M}+\mathrm{H}]^{+}=392.1067$, calculated for $\mathrm{C}_{21} \mathrm{H}_{16} \mathrm{~N}_{5} \mathrm{Cl}_{1}=392.1072$.

7-Chloro-N-(2-(4-(4-ethynyl-2-fluorophenyl)-1H-1,2,3-triazol-1-yl)ethyl)quinolin-4-amine (JR3): yield $62 \mathrm{mg}(0.16 \mathrm{mmol}, 40 \%) .{ }^{1} \mathrm{H}$ NMR $(500 \mathrm{MHz}, \mathrm{DMF}-[\mathrm{d} 7]): \delta=9.68(\mathrm{t}, J=5.96 \mathrm{~Hz}, 1 \mathrm{H}), 8.75(\mathrm{~d}, J=$ $7.14 \mathrm{~Hz}, 1 \mathrm{H}), 8.68(\mathrm{~d}, J=3.8 \mathrm{~Hz}, 1 \mathrm{H}), 8.60(\mathrm{~d}, J=9.2 \mathrm{~Hz}, 1 \mathrm{H}), 8.21(\mathrm{t}, J=8.0 \mathrm{~Hz}, 1 \mathrm{H}), 8.20(\mathrm{~d}, J=2.0$, $1 \mathrm{H}), 7.81(\mathrm{dd}, J=2.0,9.14 \mathrm{~Hz}, 1 \mathrm{H}), 7.49(\mathrm{dd}, J=1.55,3.8 \mathrm{~Hz}, 1 \mathrm{H}), 7.48(\mathrm{dd}, J=1.35,7.05 \mathrm{~Hz}, 1 \mathrm{H}), 7.20$ $(\mathrm{d}, J=7.0 \mathrm{~Hz}, 1 \mathrm{H}), 5.02(\mathrm{t}, J=5.8 \mathrm{~Hz}, 2 \mathrm{H}), 4.35(\mathrm{~s}, 1 \mathrm{H}), 4.35(\mathrm{dd}, J=5.5,5.8 \mathrm{~Hz}, 2 \mathrm{H}) \mathrm{ppm} ;{ }^{13} \mathrm{C} \mathrm{NMR}$ (125 MHz, $\mathrm{CDCl}_{3}$-[d1]): $\delta=160.0,158.5,157.3,144.9,140.7,140.5,139.8,129.8,128.6,126.4,126.1,124.1$, 121.0, 120.3, 117.2, 100.2, 83.2, 82.7, 49.4, 44.6 ppm; HR-ESI-MS $\left(\mathrm{ESI}^{+}\right):[\mathrm{M}+\mathrm{H}]^{+}=392.1067$, calculated for $\mathrm{C}_{21} \mathrm{H}_{16} \mathrm{~N}_{5} \mathrm{Cl}_{1}=392.1072$

The synthesis of the derivatives cobalamine-1,4-diethynylbenzene $\left(B_{12}-1\right)$, cobalamine-1,4diethynyl-1-fluorobenzene $\left(\mathrm{B}_{12}-\mathrm{F} 1\right)$ and cobalamine-1,4-diethynyl-2-fluorobenzene $\left(\mathrm{B}_{12}-\mathrm{F} 2\right)$ was adapted from the reference 29. A mixture of cyanocobalamin $(60 \mathrm{mg}, 0.04 \mathrm{mmol}, 1 \mathrm{eq}$.$) , CuAcO$ (7 mg, $0.004 \mathrm{mmol}, 0.1$ eq.) and the respective alkynes $(0.4 \mathrm{mmol}, 10$ eq.) in DMA $(10 \mathrm{~mL})$ was stirred until dissolution. DBU $(0.03 \mathrm{~mL}, 0.21 \mathrm{mmol}, 5$ eq. $)$ was added and the solutions allowed to react at room temperature for $4 \mathrm{~h}$. The respective crudes were precipitated by dropwise addition to the stirred solutions of diethyl ether/ $\mathrm{CH}_{2} \mathrm{Cl}_{2}(150 \mathrm{~mL}, 1: 1)$. The residues were dissolved in a mixture of $\mathrm{CH}_{3} \mathrm{OH}$ and water $(1.5 \mathrm{~mL}, 1: 1)$, filtered again and purified by preparative HPLC using system 1 for the mixture $B_{12}-F 1$ and $B_{12}-F 2$ and system 2 for $B_{12}-1$. The eluting bands containing the desired products were isolated and lyophilized. The antimalarial $\mathrm{B}_{12}$ were similarly prepared by $\mathrm{Cu}(\mathrm{I})$-catalyzed azide-alkyne cycloaddition reaction. For the compound cobalamin-7-chloro- $N$-(2-(4-(4-ethynylphenyl)-1H-1,2,3-triazol-1-yl)ethyl)quinolin-4-amine (B 12 -JR1), a mixture of $\mathrm{N}_{3}-\mathrm{CQ}(10 \mathrm{mg}, 0.04 \mathrm{mmol}, 1$ eq.) and TBTA (1 mg, 0,002 mmol, $5 \mathrm{~mol}-\%)$ was dissolved 
in DMF (0.6 mL). To this solution was added a water mixture $(0.4 \mathrm{~mL})$ of $\mathrm{B}_{12-} \mathbf{1}(60 \mathrm{mg}, 0.04 \mathrm{mmol}$, 1 eq.) $\mathrm{CuSO}_{4} \cdot 5 \mathrm{H}_{2} \mathrm{O}(0.5 \mathrm{mg}, 0,002 \mathrm{mmol}, 5 \mathrm{~mol}-\%)$ and sodium ascorbate $(0.8 \mathrm{mg}, 0,004 \mathrm{mmol}, 0,1$ eq. $)$. The compounds were reacted overnight with stirring at room temperature. For the compounds cobalamin-7-chloro-N-(2-(4-(4-ethynyl-3-fluorophenyl)-1H-1,2,3-triazol-1-yl)ethyl)quinolin-4-amine $\left(B_{12}-J R 2\right)$ and cobalamin-7-chloro-N-(2-(4-(4-ethynyl-2-fluorophenyl)-1H-1,2,3-triazol-1-yl)ethyl) quinolin-4-amine $\left(\mathrm{B}_{12}-\mathrm{JR} 3\right)$, the same procedure was repeated but cyanocobalamin was replaced by the respective $\mathrm{B}_{12}$ precursors, $\mathrm{B}_{12}-\mathrm{F} 1$ and $\mathrm{B}_{12}-\mathrm{F} 2$ respectively $(59 \mathrm{mg}, 0.04 \mathrm{mmol}, 1$ eq.). The residues were dissolved in a mixture of $\mathrm{CH}_{3} \mathrm{OH}$ and water $(1.5 \mathrm{~mL}, 1: 1)$, filtered again and purified by preparative HPLC using system 2 for both $\mathrm{B}_{12}-\mathrm{JR} 2$ and $\mathrm{B}_{12}-\mathrm{JR} 3$. The eluting bands containing the desired products were isolated and lyophilized.

Cobalamine-1,4-diethynyl-1-fluorobenzene $\left(\mathrm{B}_{12}\right.$-F1): Yield $24.2 \mathrm{mg}(0,017 \mathrm{mmol}, 41 \%) .{ }^{1} \mathrm{H}$ NMR (500 MHz, MeOD-[d4]): $\delta=7.24(\mathrm{~s}, 2 \mathrm{H}), 7.02(\mathrm{~s}, 1 \mathrm{H}), 7.01(\mathrm{~d}, J=7.9 \mathrm{~Hz}, 1 \mathrm{H}), 6.81(\mathrm{~d}, J=7.9 \mathrm{~Hz}, 1 \mathrm{H})$, $6.65(\mathrm{~s}, 1 \mathrm{H}), 6.28(\mathrm{~d}, J=3.12 \mathrm{~Hz}, 1 \mathrm{H}), 6.02(\mathrm{~s}, 1 \mathrm{H}), 4.73-4.65(\mathrm{~m}, 1 \mathrm{H}), 4.63(\mathrm{~d}, J=8.25 \mathrm{~Hz}, 1 \mathrm{H}), 4.44(\mathrm{~d}$, $J=11.3 \mathrm{~Hz}, 1 \mathrm{H}), 4.39-4.31(\mathrm{~m}, 1 \mathrm{H}), 4.22(\mathrm{~d}, J=3.6 \mathrm{~Hz}, 1 \mathrm{H}), 4.15-4.09(\mathrm{~m}, 1 \mathrm{H}), 3.94(\mathrm{dd}, J=3.2,12.7$ $\mathrm{Hz}, 1 \mathrm{H}), 3.78(\mathrm{dd}, J=4.3,12.7 \mathrm{~Hz}, 1 \mathrm{H}), 3.69(\mathrm{~d}, J=14.0 \mathrm{~Hz}, 1 \mathrm{H}), 3.64(\mathrm{q}, J=5 \mathrm{~Hz}, 1 \mathrm{H}), 3.56(\mathrm{~s}, 1 \mathrm{H})$, $3.24(\mathrm{~d}, J=10.0 \mathrm{~Hz}, 1 \mathrm{H}), 2.92-2.82(\mathrm{~m}, 2 \mathrm{H}), 2.65-2.59(\mathrm{~m}, 16 \mathrm{H}), 2.57(\mathrm{~d}, J=4.88 \mathrm{~Hz}, 6 \mathrm{H}), 2.56-2.50(\mathrm{~m}$, $4 \mathrm{H}), 2.35(\mathrm{~s}, 1 \mathrm{H}), 2.30(\mathrm{~d}, J=3 \mathrm{~Hz}, 3 \mathrm{H}), 2.28-2.19(\mathrm{~m}, 2 \mathrm{H}), 2.13-1.91(\mathrm{~m}, 6 \mathrm{H}), 1.87(\mathrm{~s}, 3 \mathrm{H}), 1.86-1.70$ $(\mathrm{m}, 3 \mathrm{H}), 1.48(\mathrm{~s}, 3 \mathrm{H}), 1.41-1.38(\mathrm{~m}, 1 \mathrm{H}), 1.37(\mathrm{~m}, 3 \mathrm{H}), 1.35-1.32(\mathrm{~m}, 1 \mathrm{H}), 1.27(\mathrm{~d}, J=6.24 \mathrm{~Hz}, 3 \mathrm{H})$, 1.24-1.16 (m, 1H), $1.14(\mathrm{~s}, 3 \mathrm{H}), 0.52(\mathrm{~s}, 3 \mathrm{H})$ ppm; HR-ESI-MS $\left(\mathrm{ESI}^{+}\right)$: $[\mathrm{M}+\mathrm{H}]^{+}=1472.5989$, calculated for $\mathrm{C}_{72} \mathrm{H}_{93} \mathrm{~N}_{13} \mathrm{O}_{14} \mathrm{Co}_{1} \mathrm{P}_{1} \mathrm{~F}_{1}=1472.6013$

Cobalamine-1,4-diethynyl-2-fluorobenzene $\left(\mathrm{B}_{12}-\mathrm{F} 2\right)$ : Yield $22.5 \mathrm{mg}(0,015 \mathrm{mmol}, 38 \%) .{ }^{1} \mathrm{H} \mathrm{NMR}$ (500 MHz, MeOD-[d4]): $\delta=7.24(\mathrm{~d}, J=4.32 \mathrm{~Hz}, 1 \mathrm{H}), 7.20(\mathrm{t}, J=7.82 \mathrm{~Hz}, 1 \mathrm{~h}), 6.64(\mathrm{ps}, 1 \mathrm{H}), 6.62(\mathrm{~d}$, $J=7.17 \mathrm{~Hz}, 1 \mathrm{H}), 6.56(\mathrm{~d}, J=10.4 \mathrm{~Hz}, 1 \mathrm{H}), 6.28(\mathrm{~d}, J=3.12 \mathrm{~Hz}, 1 \mathrm{H}), 6.02(\mathrm{~s}, 1 \mathrm{H}), 4.73-4.65(\mathrm{~m}, 1 \mathrm{H})$, $4.63(\mathrm{~d}, J=8.25 \mathrm{~Hz}, 1 \mathrm{H}), 4.44(\mathrm{~d}, J=11.3 \mathrm{~Hz}, 1 \mathrm{H}), 4.39-4.31(\mathrm{~m}, 1 \mathrm{H}), 4.22(\mathrm{~d}, J=3.6 \mathrm{~Hz}, 1 \mathrm{H}), 4.15-4.09$ $(\mathrm{m}, 1 \mathrm{H}), 3.94(\mathrm{dd}, J=3.2,12.7 \mathrm{~Hz}, 1 \mathrm{H}), 3.78(\mathrm{dd}, J=4.3,12.7 \mathrm{~Hz}, 1 \mathrm{H}), 3.69(\mathrm{~d}, J=14.0 \mathrm{~Hz}, 1 \mathrm{H}), 3.64$ $(\mathrm{q}, J=5 \mathrm{~Hz}, 1 \mathrm{H}), 3.56(\mathrm{~s}, 1 \mathrm{H}), 3.24(\mathrm{~d}, J=10.0 \mathrm{~Hz}, 1 \mathrm{H}), 2.92-2.82(\mathrm{~m}, 2 \mathrm{H}), 2.65-2.59(\mathrm{~m}, 16 \mathrm{H}), 2.57(\mathrm{~d}$, $J=4.88 \mathrm{~Hz}, 6 \mathrm{H}), 2.56-2.50(\mathrm{~m}, 4 \mathrm{H}), 2.35(\mathrm{~s}, 1 \mathrm{H}), 2.30(\mathrm{~d}, J=3 \mathrm{~Hz}, 3 \mathrm{H}), 2.28-2.19(\mathrm{~m}, 2 \mathrm{H}), 2.13-1.91$ $(\mathrm{m}, 6 \mathrm{H}), 1.87(\mathrm{~s}, 3 \mathrm{H}), 1.86-1.70(\mathrm{~m}, 3 \mathrm{H}), 1.48(\mathrm{~s}, 3 \mathrm{H}), 1.41-1.38(\mathrm{~m}, 1 \mathrm{H}), 1.37(\mathrm{~m}, 3 \mathrm{H}), 1.35-1.32(\mathrm{~m}$, $1 \mathrm{H}), 1.27(\mathrm{~d}, J=6.24 \mathrm{~Hz}, 3 \mathrm{H}), 1.24-1.16(\mathrm{~m}, 1 \mathrm{H}), 1.14(\mathrm{~s}, 3 \mathrm{H}), 0.52(\mathrm{~s}, 3 \mathrm{H}) \mathrm{ppm}$; HR-ESI-MS $\left(\mathrm{ESI}^{+}\right)$: $[\mathrm{M}+\mathrm{H}]^{+}=1472.5989$, calculated for $\mathrm{C}_{72} \mathrm{H}_{93} \mathrm{~N}_{13} \mathrm{O}_{14} \mathrm{Co}_{1} \mathrm{P}_{1} \mathrm{~F}_{1}=1472.6013$

Cobalamin-7-chloro-N-(2-(4-(4-ethynylphenyl)-1H-1,2,3-triazol-1-yl)ethyl)quinolin-4-amine (B $\left.{ }_{12}-\mathrm{JR1}\right)$ : Yield $51.6 \mathrm{mg}(0,03 \mathrm{mmol}, 75 \%) .{ }^{1} \mathrm{H} \mathrm{NMR}\left(500 \mathrm{MHz}, \mathrm{D}_{2} \mathrm{O}-[\mathrm{d} 1]\right): \delta=8.10(\mathrm{~s}, 1 \mathrm{H}), 8.08(\mathrm{~d}, J=7.30 \mathrm{~Hz}$, $1 \mathrm{H}), 7.95(\mathrm{~d}, J=9.1 \mathrm{~Hz}, 1 \mathrm{H}), 7.49(\mathrm{~d}, J=1.9 \mathrm{~Hz}, 1 \mathrm{H}), 7.39(\mathrm{dd}, J=1.9,9.13 \mathrm{~Hz}, 1 \mathrm{H}), 7.26(\mathrm{~d}, J=1.45$ $\mathrm{Hz}, 2 \mathrm{H}), 7.23(\mathrm{~s}, 1 \mathrm{H}), 7.10(\mathrm{~s}, 1 \mathrm{H}), 6.89(\mathrm{~d}, J=8.3 \mathrm{~Hz}, 2 \mathrm{H}), 6.54(\mathrm{~s}, 1 \mathrm{H}), 6.48(\mathrm{~d}, J=7.25 \mathrm{~Hz}, 1 \mathrm{H}), 6.35$ $(\mathrm{d}, J=2.91 \mathrm{~Hz}, 1 \mathrm{H}), 5.94(\mathrm{~s}, 1 \mathrm{H}), 4.76-4.70(\mathrm{~m}, 2 \mathrm{H}), 4.36-4.24(\mathrm{~m}, 4 \mathrm{H}), 4.18-4.12(\mathrm{~m}, 2 \mathrm{H}), 4.11-4.04(\mathrm{~m}$, $2 \mathrm{H}), 4.94(\mathrm{~d}, J=12.9 \mathrm{~Hz}, 1 \mathrm{H}), 3.77(\mathrm{dd}, J=3.9,12.9 \mathrm{~Hz}, 1 \mathrm{H}), 3.59(\mathrm{~d}, J=14.7 \mathrm{~Hz}, 1 \mathrm{H}), 3.20(\mathrm{dd}, J=5.0$, $11.0 \mathrm{~Hz}, 1 \mathrm{H}), 3.04(\mathrm{~d}, J=10.0 \mathrm{~Hz}, 1 \mathrm{H}), 2.96(\mathrm{dd}, J=9.13,14.3 \mathrm{~Hz}, 1 \mathrm{H}), 2.76-2.45(\mathrm{~m}, 13 \mathrm{H}), 2.46-2.32(\mathrm{~m}$, $6 \mathrm{H}), 2.26(\mathrm{~s}, 6 \mathrm{H}), 2.20-2.07(\mathrm{~m}, 3 \mathrm{H}), 2.06-1.90(\mathrm{~m}, 5 \mathrm{H}), 1.86(\mathrm{~s}, 3 \mathrm{H}), 1.82-1.69(\mathrm{~m}, 3 \mathrm{H}), 1.38(\mathrm{~s}, 3 \mathrm{H}), 1.36(\mathrm{~s}$, $3 \mathrm{H}), 1.26(\mathrm{~d}, J=6.3 \mathrm{~Hz}, 3 \mathrm{H}), 1.18(\mathrm{~s}, 3 \mathrm{H}), 1.13-1.01(\mathrm{~m}, 2 \mathrm{H}), 0.97(\mathrm{~s}, 3 \mathrm{H}), 0.46(\mathrm{~s}, 3 \mathrm{H}) \mathrm{ppm}$; HR-ESI-MS $\left(\mathrm{ESI}^{+}\right):[\mathrm{M}+2 \mathrm{H}]^{2+}=851.3401$, calculated for $\mathrm{C}_{83} \mathrm{H}_{105} \mathrm{~N}_{18} \mathrm{O}_{14} \mathrm{Co}_{1} \mathrm{P}_{1} \mathrm{Cl}_{1}(2+)=851.3402$.

Cobalamin-7-chloro-N-(2-(4-(4-ethynyl-3-fluorophenyl)-1H-1,2,3-triazol-1-yl)ethyl)quinolin-4-amine (B 12 -JR2): Yield $41.7 \mathrm{mg}(0,024 \mathrm{mmol}, 60 \%) .{ }^{1} \mathrm{H}$ NMR (500 MHz, $\left.\mathrm{D}_{2} \mathrm{O}-[\mathrm{d} 1]\right): \delta=8.10(\mathrm{~s}, 1 \mathrm{H}), 8.09$ (d, $J=6.0 \mathrm{~Hz}, 1 \mathrm{H}), 8.01(\mathrm{~d}, J=8.0 \mathrm{~Hz}, 1 \mathrm{H}), 7.54(\mathrm{~d}, J=1.94 \mathrm{~Hz}, 1 \mathrm{H}), 7.48(\mathrm{dd}, J=1.9,9.3 \mathrm{~Hz}, 1 \mathrm{H}), 7.28(\mathrm{~s}$, $1 \mathrm{H}), 7.14(\mathrm{~s}, 1 \mathrm{H}), 7.01(\mathrm{~s}, 1 \mathrm{H}), 6.95(\mathrm{~d}, J=3.0 \mathrm{~Hz}, 1 \mathrm{H}), 6.90(\mathrm{~d}, J=7.8 \mathrm{~Hz}, 1 \mathrm{H}), 6.56(\mathrm{~s}, 1 \mathrm{H}), 6.48(\mathrm{~d}$, $J=7.3 \mathrm{~Hz}, 1 \mathrm{H}), 6.37(\mathrm{~d}, J=3.13 \mathrm{~Hz}, 1 \mathrm{H}), 6.0(\mathrm{~s}, 1 \mathrm{H}), 4.76-4.70(\mathrm{~m}, 2 \mathrm{H}), 4.36-4.24(\mathrm{~m}, 4 \mathrm{H}), 4.18-4.12$ $(\mathrm{m}, 2 \mathrm{H}), 4.11-4.04(\mathrm{~m}, 2 \mathrm{H}), 4.94(\mathrm{~d}, J=12.9 \mathrm{~Hz}, 1 \mathrm{H}), 3.77(\mathrm{dd}, J=3.9,12.9 \mathrm{~Hz}, 1 \mathrm{H}), 3.59(\mathrm{~d}, J=14.7$ $\mathrm{Hz}, 1 \mathrm{H}), 3.20(\mathrm{dd}, J=5.0,11.0 \mathrm{~Hz}, 1 \mathrm{H}), 3.04(\mathrm{~d}, J=10.0 \mathrm{~Hz}, 1 \mathrm{H}), 2.96(\mathrm{dd}, J=9.13,14.3 \mathrm{~Hz}, 1 \mathrm{H})$, 2.76-2.45 (m, 13H), 2.46-2.32 (m, 6H), $2.26(\mathrm{~s}, 6 \mathrm{H}), 2.20-2.07(\mathrm{~m}, 3 \mathrm{H}), 2.06-1.90(\mathrm{~m}, 5 \mathrm{H}), 1.86(\mathrm{~s}, 3 \mathrm{H})$, 1.82-1.69 (m, 3H), $1.38(\mathrm{~s}, 3 \mathrm{H}), 1.36(\mathrm{~s}, 3 \mathrm{H}), 1.26(\mathrm{~d}, J=6.3 \mathrm{~Hz}, 3 \mathrm{H}), 1.18(\mathrm{~s}, 3 \mathrm{H}), 1.13-1.01(\mathrm{~m}, 2 \mathrm{H})$, 
$0.97(\mathrm{~s}, 3 \mathrm{H}), 0.38(\mathrm{~s}, 3 \mathrm{H}) \mathrm{ppm}$; HR-ESI-MS $\left(\mathrm{ESI}^{+}\right):[\mathrm{M}+\mathrm{Na}]^{+}=1741.6457$, calculated for $\mathrm{C}_{83} \mathrm{H}_{102}$ $\mathrm{N}_{18} \mathrm{O}_{14} \mathrm{Co}_{1} \mathrm{P}_{1} \mathrm{~F}_{1} \mathrm{Na}_{1}=1741.6457$.

Cobalamin-7-chloro-N-(2-(4-(4-ethynyl-2-fluorophenyl)-1H-1,2,3-triazol-1-yl)ethyl)quinolin-4-amine (B 12 -JR3): Yield $48.8 \mathrm{mg}(0.028 \mathrm{mmol}, 75 \%) .{ }^{1} \mathrm{H}$ NMR (500 MHz, $\left.\mathrm{D}_{2} \mathrm{O}-[\mathrm{d} 1]\right): \delta=8.00(\mathrm{~d}, J=7.0 \mathrm{H} 1 \mathrm{H})$, $7.97(\mathrm{~s}, 1 \mathrm{H}), 7.46(\mathrm{t}, J=7.9 \mathrm{~Hz}, 1 \mathrm{H}), 7.31(\mathrm{ps}, 1 \mathrm{H}), 7.17(\mathrm{~s}, 1 \mathrm{H}), 7.09(\mathrm{~d}, J=8.6 \mathrm{~Hz}, 1 \mathrm{H}), 7.00(\mathrm{~s}, 1 \mathrm{H}), 6.63$ $(\mathrm{d}, J=8.09 \mathrm{~Hz}, 1 \mathrm{H}), 6.45(\mathrm{~d}, J=9.6 \mathrm{~Hz}, 1 \mathrm{H}), 6.43(\mathrm{~s}, 1 \mathrm{H}), 6.38(\mathrm{~d}, J=6.8 \mathrm{~Hz}, 1 \mathrm{H}), 6.26(\mathrm{~d}, J=2.8 \mathrm{~Hz}, 1 \mathrm{H})$, $5.8(\mathrm{~s}, 1 \mathrm{H}), 4.76-4.70(\mathrm{~m}, 2 \mathrm{H}), 4.36-4.24(\mathrm{~m}, 4 \mathrm{H}), 4.18-4.12(\mathrm{~m}, 2 \mathrm{H}), 4.11-4.04(\mathrm{~m}, 2 \mathrm{H}), 4.94(\mathrm{~d}, J=12.9$ $\mathrm{Hz}, 1 \mathrm{H}), 3.77(\mathrm{dd}, J=3.9,12.9 \mathrm{~Hz}, 1 \mathrm{H}), 3.59(\mathrm{~d}, J=14.7 \mathrm{~Hz}, 1 \mathrm{H}), 3.20(\mathrm{dd}, J=5.0,11.0 \mathrm{~Hz}, 1 \mathrm{H}), 3.04(\mathrm{~d}$, $J=10.0 \mathrm{~Hz}, 1 \mathrm{H}), 2.96(\mathrm{dd}, J=9.13,14.3 \mathrm{~Hz}, 1 \mathrm{H}), 2.76-2.45(\mathrm{~m}, 13 \mathrm{H}), 2.46-2.32(\mathrm{~m}, 6 \mathrm{H}), 2.26(\mathrm{~s}, 6 \mathrm{H})$, 2.20-2.07 (m, 3H), 2.06-1.90 (m, 5H), $1.86(\mathrm{~s}, 3 \mathrm{H}), 1.82-1.69(\mathrm{~m}, 3 \mathrm{H}), 1.38(\mathrm{~s}, 3 \mathrm{H}), 1.28(\mathrm{~s}, 3 \mathrm{H}), 1.24(\mathrm{~s}$, $3 \mathrm{H}), 1.17(\mathrm{~d}, J=6.23 \mathrm{~Hz}, 3 \mathrm{H}), 1.03(\mathrm{~s}, 1 \mathrm{H}), 0.78(\mathrm{~s}, 3 \mathrm{H}), 0.36(\mathrm{~s}, 3 \mathrm{H})$ ppm; HR-ESI-MS $\left(\mathrm{ESI}^{+}\right):\left[\mathrm{M}+\mathrm{Na}^{+}\right.$ $=1741.6457$, calculated for $\mathrm{C}_{83} \mathrm{H}_{102} \mathrm{~N}_{18} \mathrm{O}_{14} \mathrm{Co}_{1} \mathrm{P}_{1} \mathrm{~F}_{1} \mathrm{Na}_{1}=1741.6457$.

Synthesis of 2-azido-1-(2-(4-fluorophenyl)-3-((4-fluorophenyl)amino)-8,8-dimethyl-5,6-dihydroimidazo [1,2-a]pyrazin-7(8H)-yl)ethan-1-one ( $\mathbf{N}_{3}$-SN1): To the solution of KAF156 (100 mg, $\left.0.024 \mathrm{mmol}, 1.0 \mathrm{eq}\right)$ in dry acetonitrile $(10 \mathrm{~mL})$ under argon, 2-azido-1,3-dimethylimidazolinium hexafluorophosphate (90 mg, $0.031 \mathrm{mmol}, 1.3 \mathrm{eq})$ and trimethylamine andydruos $(180 \mu \mathrm{L}, 0.121 \mathrm{mmol}, 5.0 \mathrm{eq})$ were added. The mixture was then heated to $30^{\circ} \mathrm{C}$ and stirred for $4 \mathrm{~h}$. After the reaction completion, the solvent was evaporated, DCM $(20 \mathrm{~mL})$ and water $(20 \mathrm{~mL})$ were added to the residue and the two phases were separated. The aqueous phase was extracted with $2 \times 20 \mathrm{~mL}$ of $\mathrm{CH}_{2} \mathrm{Cl}_{2}$. The combined organic layers were washed with brine $(20 \mathrm{~mL})$, separated and dried over $\mathrm{Na}_{2} \mathrm{SO}_{4}$. The mixture was filtered and the solvent was removed under reduced pressure. The crude product was purified by flash column chromatography to afford compound $\mathrm{N}_{3}$-SN1 as a white solid. Yield: $85 \mathrm{mg}(0.194 \mathrm{mmol}, 80 \%) .{ }^{1} \mathrm{H}$ NMR (400 MHz, MeOD-[d4]): $\delta=7.73(\mathrm{dd}, J=5.2,5.92 \mathrm{~Hz}, 2 \mathrm{H}), 7.04(\mathrm{dd}, J=8.68 \mathrm{~Hz}, 2 \mathrm{H}), 6.91(\mathrm{dd}$, $J=8.96 \mathrm{~Hz}, 2 \mathrm{H}), 6.57(\mathrm{dd}, J=4.32,6.8 \mathrm{~Hz}, 2 \mathrm{H}), 4.17(\mathrm{~s}, 2 \mathrm{H}), 3.84(\mathrm{t}, J=5.36,2 \mathrm{H}), 3.68(\mathrm{t}, J=5.76,2 \mathrm{H})$, $1.97(\mathrm{~s}, 6 \mathrm{H}),=5.8 \mathrm{HR}$-ESI-MS $\left(\mathrm{ESI}^{+}\right):[\mathrm{M}+\mathrm{H}]^{+}=437.47$, calculated for $\mathrm{C}_{22} \mathrm{H}_{21} \mathrm{~F}_{2} \mathrm{~N}_{7} \mathrm{O}=437.17$.

Synthesis of 2-(4-(4-ethynylphenyl)-1H-1,2,3-triazol-1-yl)-1-(2-(4-fluorophenyl)-3-((4-fluorophenyl) amino)-8,8-dimethyl-5,6-dihydroimidazo[1,2-a]pyrazin-7(8H)-yl)ethan-1-one (SN1): A mixture of $\mathrm{N}_{3}$-SN1 (85 mg, $0.194 \mathrm{mmol}, 1$ eq.), 1,4-diethynylbenzene ( $29.40 \mathrm{mg}, 0.233 \mathrm{mmol}, 1.2$ eq.) and $\mathrm{Et}_{3} \mathrm{~N}$ (7.87 mg, $0.077 \mathrm{mmol}, 40 \mathrm{~mol}-\%)$ was dissolved in DMF (1 mL). CuI (3.70 mg, $0.019 \mathrm{mmol}, 10 \mathrm{~mol}-\%)$ was added to this solution. The compounds were reacted overnight with stirring at room temperature. After the reaction completion, brine $(20 \mathrm{~mL})$ and dichloromatane $(20 \mathrm{~mL})$ were added to the solution. The aqueous phase was extracted with $2 \times 20 \mathrm{~mL}$ of $\mathrm{CH}_{2} \mathrm{Cl}_{2}$. The combined organic layers were washed with brine $(20 \mathrm{~mL})$ and the organic layer separated and dried over $\mathrm{Na}_{2} \mathrm{SO}_{4}$. Then, the mixture was filtered and finally $\mathrm{CH}_{2} \mathrm{Cl}_{2}$ was removed under reduced pressure. The crude product was purified by flash column chromatography to afford compound SN1 as a white solid. Yield: $93 \mathrm{mg}(0.165 \mathrm{mmol}$, $85 \%) .{ }^{1} \mathrm{H}$ NMR $\left(400 \mathrm{MHz},\left(\mathrm{CD}_{3}\right)_{2} \mathrm{CO}-[\mathrm{d} 6]\right): \delta=8.22(\mathrm{~s}, 2 \mathrm{H}), 7.78(\mathrm{~m}, 4 \mathrm{H}), 7.43(\mathrm{~d}, J=8.4 \mathrm{~Hz}, 2 \mathrm{H}), 6.92$ $(\mathrm{d}, J=8.62 \mathrm{H}), 6.82(\mathrm{dd}, J=8.562 \mathrm{H}), 6.56(\mathrm{dd}, J=4.48,8.92 \mathrm{~Hz} 2 \mathrm{H}), 5.52(\mathrm{~s}, 2 \mathrm{H}), 3.89(\mathrm{t}, J=5.6 \mathrm{~Hz}, 2 \mathrm{H})$, $3.85(\mathrm{t}, J=5.40 \mathrm{~Hz}, 2 \mathrm{H}), 3.55(\mathrm{~s}, 1 \mathrm{H}), 1.77(\mathrm{~s}, 6 \mathrm{H}) ;$ HR-ESI-MS $\left(\mathrm{ESI}^{+}\right):[\mathrm{M}+\mathrm{H}]^{+}=564.23$, calculated for $\mathrm{C}_{32} \mathrm{H}_{28} \mathrm{~F}_{2} \mathrm{~N}_{7} \mathrm{O}=564.23$.

Synthesis of Cobalamin-2-(4-(4-ethynylphenyl)-1H-1,2,3-triazol-1-yl)-1-(2-(4-fluorophenyl)-3((4-fluorophenyl)amino)-8,8-dimethyl-5,6-dihydroimidazo[1,2-a]pyrazin-7(8H)-yl)ethan-1-one (B12-SN1): a mixture of $\mathrm{N}_{3}$-SN1 (50 mg, $0.114 \mathrm{mmol}, 1$ eq.) and TBTA ( $\left.3.03 \mathrm{mg}, 0,005 \mathrm{mmol}, 5 \mathrm{~mol}-\%\right)$ was dissolved in DMF $(1 \mathrm{~mL})$. To this solution a water mixture $(0.4 \mathrm{~mL})$ of $\mathrm{B}_{12-} \mathbf{1}(166 \mathrm{mg}, 0.114 \mathrm{mmol}$, 1 eq.) $\mathrm{CuSO}_{4} \cdot 5 \mathrm{H}_{2} \mathrm{O}(1.42 \mathrm{mg}, 0,005 \mathrm{mmol}, 5 \mathrm{~mol}-\%)$ and sodium ascorbate $(2.26 \mathrm{mg}, 0,011 \mathrm{mmol}$, 0.1 eq.) was added. The mixture stirred overnight at room temperature. The residues were dissolved in a mixture of $\mathrm{CH}_{3} \mathrm{OH}$ and water $(1.5 \mathrm{~mL}, 1: 1)$, filtered again and purified by preparative HPLC using. The eluting bands containing the desired products were isolated and lyophilized. The pure product $\left(B_{12}\right.$-SN1) was obtained as a red solid. Yield: $116.70 \mathrm{mg}(0.080 \mathrm{mmol}, 70 \%) ;{ }^{1} \mathrm{H} \mathrm{NMR}(400 \mathrm{MHz}$, $\left.\mathrm{D}_{2} \mathrm{O}-[\mathrm{d} 1]\right): \delta=8.19(\mathrm{~s}, 1 \mathrm{H}), 7.73(\mathrm{dd}, J=5.4,14.4 \mathrm{~Hz}, 2 \mathrm{H}), 7.57(\mathrm{~d}, J=8.3 \mathrm{~Hz}, 1 \mathrm{H}), 7.25(\mathrm{~s}, 2 \mathrm{H}), 7.04$ $(\mathrm{t}, J=6.84 \mathrm{~Hz}, 1 \mathrm{H}), 6.92(\mathrm{dd}, J=8.414 .96 \mathrm{~Hz}, 4 \mathrm{H}), 6.66(\mathrm{~s}, 1 \mathrm{H}), 6.58(\mathrm{dd}, J=4.4,4.522 \mathrm{H}), 6.23(\mathrm{~d}$, 
$J=3.12 \mathrm{~Hz}, 1 \mathrm{H}), 6.02(\mathrm{~s}, 1 \mathrm{H}), 5.56(\mathrm{~d}, J=7.0 \mathrm{~Hz}, 1 \mathrm{H}), 4.76-4.60(\mathrm{~m}, 3 \mathrm{H}), 4.45(\mathrm{~d}, J=11.48,1 \mathrm{H}), 4.4-4.30$ $(\mathrm{m}, 1 \mathrm{H}), 4.22(\mathrm{t}, J=3.6,1 \mathrm{H}), 4.16-4.10(\mathrm{~m}, 1 \mathrm{H}), 3.95(\mathrm{dd}, J=1.62,11.02 \mathrm{~Hz}, 1 \mathrm{H}), 3.79(\mathrm{dd}, J=4.36$, $10.42 \mathrm{~Hz}, 1 \mathrm{H}), 3.69(\mathrm{~d}, J=13.88 \mathrm{~Hz}, 1 \mathrm{H}), 3.59(\mathrm{dd}, J=4.96,8.16 \mathrm{~Hz}, 1 \mathrm{H}), 3.26(\mathrm{~d}, J=9.76 \mathrm{~Hz}, 1 \mathrm{H})$, $2.87(\mathrm{~m}, 2 \mathrm{H}), 2.66-2.2(\mathrm{~m}, 13 \mathrm{H}), 2.50-2.43(\mathrm{~m}, 3 \mathrm{H}), 2.37(\mathrm{~d}, J=13.2,1 \mathrm{H}), 2.3(\mathrm{~d}, J=4.6,6 \mathrm{H}), 2.27-2.21$ $(\mathrm{m}, 1 \mathrm{H}), 1.95(\mathrm{~s}, 6 \mathrm{H}), 1.89(\mathrm{~s}, 3 \mathrm{H}), 1.85-1.71(\mathrm{~m}, 2 \mathrm{H}), 1.49(\mathrm{~S}, 3 \mathrm{H}), 1.38(\mathrm{~s}, 3 \mathrm{H}), 1.34(\mathrm{~s}, 3 \mathrm{H}), 1.27(\mathrm{~d}$, $J=6.3 \mathrm{~Hz}, 3 \mathrm{H}), 1.17(\mathrm{~s}, 3 \mathrm{H}), 0.53(\mathrm{~s}, 3 \mathrm{H}) \mathrm{ppm}$; HR-ESI-MS $\left(\mathrm{ESI}^{+}\right):[\mathrm{M}+2 \mathrm{H}]^{2+}=945.3402$, calculated for $\left[\mathrm{C}_{95} \mathrm{H}_{115} \mathrm{CoF}_{2} \mathrm{~N}_{19} \mathrm{O}_{15} \mathrm{P}\right]^{2+}=945.9$.

\subsection{In Vitro Cytotoxicity Assay}

$\mathrm{B}_{12}$-JR1 was screened for in vitro cytotoxicity against the Chinese Hamster Ovarian (CHO) cell-line using the 3-(4,5-dimethylthiazol-2-yl)-2,5-diphenyltetrazolium bromide (MTT)-assay [59]. The test sample was prepared to a $20 \mathrm{mg} \mathrm{mL}^{-1}$ stock solution in $100 \%$ DMSO and tested in triplicate. Stock solutions were stored at $-20^{\circ} \mathrm{C}$. Further dilutions were prepared in complete medium on the day of the experiment. Samples were tested as a suspension if not completely dissolved. Emetine was used as the reference drug in all experiments. The initial concentration of emetine was $100 \mu \mathrm{g} \mathrm{mL}{ }^{-1}$, which was diluted in complete medium with 10-fold dilutions to give 6 concentrations, the lowest being $0.001 \mu \mathrm{g} \mathrm{mL} \mathrm{m}^{-1}$. The same dilution technique was applied to all test samples. The highest concentration of solvent to which the cells were exposed to have no measurable effect on the cell viability. The $50 \%$ inhibitory concentration $\left(\mathrm{IC}_{50}\right.$ ) values were obtained from full dose-response curves, using a non-linear dose-response curve fitting analysis via GraphPad Prism v.5 software. Furthermore, the cytotoxicity in terms of the antiproliferative effect of $B_{12}-J R 1, B_{12}-J R 2$ and $B_{12}-J R 3$ were similarly evaluated by the MTT assay. The assay was carried out using human lung fibroblasts (MRC5) cell line after $48 \mathrm{~h}$ of cell incubation in the medium, containing compounds at concentrations ranging from 5 to $200 \mu \mathrm{M}$. Briefly, MRC5 cells were maintained in RPMI-1640 medium supplemented with $100 \mu \mathrm{g} / \mathrm{mL}$ streptomycin, $100 \mathrm{U} / \mathrm{mL}$ penicillin and $10 \%(\mathrm{v} / \mathrm{v})$ fetal bovine serum (FBS) (Gibco) as a monolayer $\left(1 \times 10^{4}\right.$ cells per well). All cell lines were grown in humidified atmosphere of $95 \%$ air and $5 \% \mathrm{CO}_{2}$ at $37^{\circ} \mathrm{C}$. The MTT assay was performed two times in four replicates. The extent of MTT reduction was measured spectrophotometrically at $540 \mathrm{~nm}$ using a Tecan Infinite 200 Pro multiplate reader (Tecan Group Ltd., Männedorf, Switzerland), and the cell survival was expressed as percentage of the control (untreated cells). Cytotoxicity was expressed as the concentration of the compound inhibiting cell growth by $50 \%\left(\mathrm{IC}_{50}\right)$ in comparison to untreated control. The results were expressed as mean values \pm standard deviation (SD) and analysed using Student's t-test at a threshold level of $p=0.05$. Statistical analysis was carried out using SPSS 20 (SPSS Inc., Chicago, IL, USA) software. All experiments were conducted in at least three replicates.

\subsection{In Vitro Antiplasmodial Assay}

The test samples were tested in triplicate against the chloroquine-sensitive (CQS) strain of Plasmodium falciparum (NF54) and the CQ-resistant isolate (K1). Continuous in vitro cultures of asexual erythrocyte stages of $P$. falciparum were maintained using a modified method by Trager and Jensen [60]. Quantitative assessment of the antiplasmodial activity in vitro was determined via the parasite lactate dehydrogenase assay using a modified method described by Makler [61]. The test samples were prepared to a $20 \mathrm{mg} / \mathrm{mL}$ stock solution in $100 \%$ DMSO and sonicated to enhance solubility. Samples were tested as a suspension if not completely dissolved. Stock solutions were stored at $-20^{\circ} \mathrm{C}$. Further dilutions were prepared on the day of the experiment. Chloroquine (CQ) was used as the reference drug in all experiments. A full dose-response was performed for all compounds to determine the concentration inhibiting $50 \%$ of parasite growth ( $\mathrm{IC}_{50}$ value). The vitamin $\mathrm{B}_{12}$ complexes were tested at starting concentrations up to $50 \mu \mathrm{g} / \mathrm{mL}$, which was then serially diluted 2-fold in complete medium to give 10 concentrations. The ligands were tested at a starting concentration of $10 \mu \mathrm{g} / \mathrm{mL}$, which was serially diluted 2 -fold in complete medium to give 10 concentrations. CQ was tested at a starting 
concentration of $1 \mu \mathrm{g} / \mathrm{mL}$. The $\mathrm{IC}_{50}$ values were obtained using a non-linear dose-response curve fitting analysis via Graph Pad Prism v.5.0 software (GraphPad Software Inc., San Diego, CA, USA).

\subsection{In Vitro Blood Assays}

B $_{12}$-JR1-CBC was used to study in vitro bio-distribution in blood using both whole-blood and washed red blood cells. Blood was collected from a healthy dog with the consent of owner into BD Vacutainer ${ }^{\circledR}$ Plus plastic citrate tube $(2 \mathrm{~mL}$; haematocrit value of 40 , Vetlab Animal Diagnostic Laboratory, Belgrade, Serbia; http://www.vetlab.rs/) and used immediately as a whole-blood sample and for the red blood cells (RBC) preparation. The platelet rich plasma and buffy coat were discarded after centrifugation $(370 \times g, 10 \mathrm{~min})$. The erythrocytes were then washed in 10 times their volume of phosphate-buffered saline (PBS) and resuspended in isotonic PBS. The haemoglobin concentration was adjusted to $2 \mathrm{~g} / 100 \mathrm{~mL}$. To the whole-blood and to the RBC suspension $\mathrm{B}_{12}$-JR1-CBC (20 $\mu$ M final concentration) was added. The final incubation volume was $1 \mathrm{~mL}$ and the tubes were shaken on rocking platform at $37^{\circ} \mathrm{C}$ for $24 \mathrm{~h}$ in dark. At different incubation periods $(30 \mathrm{~min}, 2 \mathrm{~h}, 8 \mathrm{~h}, 12 \mathrm{~h}$ and $24 \mathrm{~h}) 5 \mu \mathrm{L}$ of the whole sample was spread on the microscopic slide for the direct examination (fluorescence microscope Olympus BX51, Applied Imaging Corp., San Jose, CA, United States; Texas Red filter), while $100 \mu \mathrm{L}$ of RBC incubation mixture was transferred into $0.5 \mathrm{~mL}$ Eppendorf tube, centrifuged briefly $(370 \times g, 1 \mathrm{~min})$ and $50 \mu \mathrm{L}$ sample of the supernatant diluted 10 -fold in PBS and analysed for B12-JR1-CBC presence using Tecan Infinite 200 Pro multiplate reader (Tecan Group, Männedorf, Switzerland; $\lambda \mathrm{Ex}=488 \mathrm{~nm}, \lambda \mathrm{Em}=540 \mathrm{~nm}$ ). The assay was performed three times in duplicate and the results were presented as percentage of the control (RBC suspension the time of the compound addition) that was arbitrarily set to $100 \%$.

\subsection{In Vivo Zebrafish Assays Toxicity}

The toxicity evaluation of $\mathrm{B}_{12}-\mathbf{J R} 1, \mathrm{~B}_{12}-\mathrm{JR} 1-\mathrm{CBC}$ and vitamin $\mathrm{B}_{12}$ in the zebrafish model was carried out according to general rules of the OECD Guidelines for the Testing of Chemicals [62]. All experiments involving zebrafish were performed in compliance with the European directive 2010/63/EU and the ethical guidelines of the Guide for Care and Use of Laboratory Animals of the Institute of Molecular Genetics and Genetic Engineering, University of Belgrade. Embryos of wild type zebrafish (Danio rerio, $\mathrm{AB}$ strain) were raised in a temperature- and light-controlled zebrafish facility with $28^{\circ} \mathrm{C}$ and standard 14:10-h light-dark photoperiod, and regularly fed with commercially dry flake food (TetraMin ${ }^{\mathrm{TM}}$ flakes; Tetra Melle, Germany) twice a day and Artemia nauplii once daily. Zebrafish embryos were produced by the pair-wise mating, collected and distributed into 24-well plates containing 10 embryos per well and $1 \mathrm{~mL}$ embryos water $\left(0.2 \mathrm{~g} \mathrm{~L}^{-1}\right.$ of Instant Ocean ${ }^{\circledR}$ Salt in distilled water), and raised at $28{ }^{\circ} \mathrm{C}$. For assessing lethal and developmental toxicity, embryos staged $6 \mathrm{~h}$ post fertilization (hpf) were treated with four concentrations of $\mathrm{B}_{12}-\mathbf{J R} \mathbf{1}$ and vitamin $\mathrm{B}_{12}(50,75,100$ and $150 \mu \mathrm{M})$ and four concentrations of $\mathrm{B}_{12}$-JR1-CBC $(20,25,50$ and $100 \mu \mathrm{M})$. DMSO $(0.25 \% v / v)$ was used as negative control. Experiments were performed three times using 30 embryos per concentration. Apical endpoints for the toxicity evaluation (Table S1) were recorded at 24, 48, 72, 96 and 120 hpf using an inverted microscope (CKX41; Olympus, Tokyo, Japan). Dead embryos were counted and discarded every $24 \mathrm{~h}$. At $120 \mathrm{hpf}$, embryos were inspected for heartbeat rate, anesthetized by addition of $0.1 \%$ $(w / v)$ tricaine solution (Sigma-Aldrich, St. Louis, MO, USA), photographed and killed by freezing at $-20{ }^{\circ} \mathrm{C}$ for $\geq 24 \mathrm{~h}$. To analyse compound $\mathrm{B}_{12}-\mathrm{JR} \mathbf{1}$ and $\mathrm{B}_{12}-\mathrm{JR1}-\mathrm{CBC}$ for possible hepatotoxic effect in vivo, the transgenic $\mathrm{Tg}$ (fabp10:EGFP) zebrafish embryos with the fluorescently labelled liver were exposed to the tested compounds at the $72 \mathrm{hpf}$ stage, when the liver is fully functional, vascularized and started metabolic transformation of absorbed compounds, assessing thus the effect of applied compounds on the liver functioning. Embryos were exposed to the range of concentrations previously determined that not affected embryos survival and development. Experiments were performed three times using 5 embryos per concentration. The hepatotoxicity was determined according to the change of liver area index compared to the control group, calculated as the ration between liver area and 
embryonic lateral area $\times 100 \%$, as reported by Zhang et al. [63]. In addition, the liver colour and retention of yolk were followed as the phenotypic signs of hepatotoxicity [64].

\subsection{Distribution}

To determine the distribution and the accumulation of $\mathrm{B}_{12}-\mathrm{JR} 1$ and $\mathrm{B}_{12}-\mathrm{JR} 1-\mathrm{CBC}$ through inner organs, transgenic $T g(f a b p: E G F P)$ zebrafish embryos were exposed to a non-toxic concentration of each of the tested compounds ( $150 \mu \mathrm{M}$ of $\mathrm{B}_{12}-\mathrm{JR} 1$ and $20 \mu \mathrm{M} \mathrm{B}_{12}-\mathrm{JR} 1-\mathrm{CBC}$ ) in a period from 72 to $120 \mathrm{hpf}$ (a long exposure started when the liver became vascularized and capable to metabolize the absorbed compounds) and 106 to $120 \mathrm{hpf}$ (a shorter exposure time). To verify a preferential accumulation of $B_{12}$-JR1-CBC in the liver, the compound was applied intravenously (parenteral use) to zebrafish embryos. The 106-hpf old embryos were anesthetized by addition of tricaine-methane sulfonate (200 $\mathrm{\mu g} / \mathrm{mL}$, Sigma-Aldrich), and microinjected by a pneumatic picopump (PV820, World Precision Instruments, USA) with $5 \mathrm{~nL}$ of $\mathrm{B}_{12}$-JR1-CBC $(9.56 \mu \mathrm{g} / \mathrm{nL}$ per an embryo, corresponding to $20 \mu \mathrm{M}$ dose applied into embryo water). The treated embryos were analysed at $120 \mathrm{hpf}$ by a fluorescent microscope (Olympus BX51, Applied Imaging Corp., San Jose, CA, USA) upon Texas Red filter (an excitation max $596 \mathrm{~nm}$, an emission max $620 \mathrm{~nm}$ ) and Spectrum Green filter (an excitation max $497 \mathrm{~nm}$, an emission $\max 524 \mathrm{~nm}$ ) to detect $\mathrm{B}_{12}$-JR1-CBC and the EGFP-labelled liver, respectively.

\section{Conclusions}

In summary, we have reported the synthesis of vitamin $B_{12}$ derivatives designed for the delivery the same antimalarial prodrug to both erythro- and hepatocytes. The drugs are released from the $\mathrm{Cbl}$ scaffold with a 4-(4-ethynylphenyl)-triazole functionality. In this proof-of-concept study, the chloroquine molecules we designed were equally active against chloroquine-resistant (CQR) and chloroquine-sensitive (CQS) P. falciparum strains, and showed no toxicity in vitro and in vivo (zebrafish model) no hepatotoxicity, no cardiotoxicity or developmental toxicity of the embryos. While we are aware that this approach may not be cost effective for the treatment of a large number of individuals, it may lead to development of antimalarial drugs of last resort or new organic drugs candidates based on the triazole functionality we selected for this study.

Supplementary Materials: The following are available online. Figure S1: $500 \mathrm{MHz}{ }^{1} \mathrm{H}-\mathrm{NMR}$ of compound JR1 (in DMF, ${ }^{*}=$ solvent residual peak), Figure S2: $500 \mathrm{MHz}{ }^{1} \mathrm{H}-\mathrm{NMR}$ of compound JR2 (in DMF, ${ }^{*}=$ solvent residual peak), Figure S3: $500 \mathrm{MHz}{ }^{1} \mathrm{H}-\mathrm{NMR}$ of compound JR3 (in DMF, ${ }^{*}=$ solvent residual peak), Figure S4: $500 \mathrm{MHz}{ }^{1} \mathrm{H}-\mathrm{NMR}$ of compound B12-F1 (in MeOD, ${ }^{*}=$ solvent residual peak), Figure S5: $500 \mathrm{MHz}{ }^{1} \mathrm{H}-\mathrm{NMR}$ of compound B12-F2 (in MeOD, * = solvent residual peak), Figure S6: $500 \mathrm{MHz}{ }^{1} \mathrm{H}-\mathrm{NMR}$ of compound B12-JR1 (in $\mathrm{D}_{2} \mathrm{O},{ }^{*}=$ solvent residual peak), Figure S7: $500 \mathrm{MHz}{ }^{1} \mathrm{H}-\mathrm{NMR}$ of compound B12-JR2 (in $\mathrm{D}_{2} \mathrm{O},{ }^{*}=$ solvent residual peak), Figure S8: $500 \mathrm{MHz}{ }^{1} \mathrm{H}-\mathrm{NMR}$ of compound B12-JR3 (in $\mathrm{D}_{2} \mathrm{O},{ }^{*}=$ solvent residual peak), Figure S9: $400 \mathrm{MHz}{ }^{1} \mathrm{H}-\mathrm{NMR}$ of compound N3-SN1 (in MeOD, ${ }^{*}=$ solvent residual peak), Figure S10: $400 \mathrm{MHz}{ }^{1} \mathrm{H}-\mathrm{NMR}$ of compound SN1 (in $\left(\mathrm{CD}_{3}\right)_{2} \mathrm{CO},{ }^{*}=$ solvent residual peak), Figure S11: $400 \mathrm{MHz}{ }^{1} \mathrm{H}-\mathrm{NMR}$ of compound B12-SN1 (in $\mathrm{D}_{2} \mathrm{O},{ }^{*}=$ solvent residual peak), Figure S12: DFT optimized structure of $N$-quinoline bound JR1 model with ferriprotoporphyrin IX, Figure S13: DFT optimized structure of $N$-triazole bound JR1 model with ferriprotoporphyrin IX, Figure S14: DFT optimized structure of $N$-quinoline protonated JR1 model interacting with ferriprotoporphyrin IX $\mu$-oxo dimer, Figure S15: HR-ESI-MS spectrum (in $\mathrm{MeOH}$ ) of compound JR1, Figure S16: HR-ESI-MS spectrum (in MeOH) of compound JR2/3, Figure S17: HR-ESI-MS spectrum (in MeOH) of compound B12-F1/2, Figure S18: HR-ESI-MS spectrum (in MeOH) of compound B12-JR1, Figure S19: HR-ESI-MS spectrum (in $\mathrm{MeOH}$ ) of compound B12-JR2/3, Figure S20: HR-ESI-MS spectrum (in MeOH) of compound B12-JR1-CBC, Figure S21: Top: distribution of compound B12-JR1-CBC in suspension of washed red blood cells (RBC) over time. RBC suspensions with (Sample) and without (Control) the molecule were incubated with $20 \mu \mathrm{M}$ (final concentration) of B12-JR1-CBC at $37^{\circ} \mathrm{C}$ for $24 \mathrm{~h}$ in dark with shaking and at various time points aliquots were centrifuged and the amount of fluorescence in the supernatant determined $(\lambda \mathrm{Ex}=488 \mathrm{~nm}, \lambda \mathrm{Em}=540 \mathrm{~nm})$. Bottom: fluorescence spectra of full smear blood control, Figure S22: Calculated IR spectrum of DFT optimized structure (gas-phase) of the interaction of a protonated 4-(4-ethynylphenyl)-triazole functionalized quinoline drug model with ferriprotoporphyrin IX $\mu$-oxo dimer shown in Figure 5 of the manuscript. Note no negative frequencies verifying a true minimum, Figure S23: Bio-distribution and accumulation of B12-JR1 and B12-JR1-CBC in the 120-hpf old transgenic $\mathrm{Tg}$ (fabp10:EGFP) zebrafish embryo with fluorescently labelled liver applied at different developmental stages, Figure S24: HPLC traces of molecules prepared in this study, Table S1: Crystallographic details of compound JR1, Table S2: Crystallographic details of compound B12-F2. 
Author Contributions: J.R., S.N.S. and A.P. equally contributed to the work. F.Z. conceived and designed the work and performed DFT calculations. J.R. and S.N.S. synthesized and characterized the compounds. S.B. performed spectroscopic titrations. S.V. and J.N.R. performed the in vitro cell assays. T.S and G.S. performed assays on $P$. falciparum. A.P. executed all in vivo experiments. All authors read and contributed to the manuscript.

Funding: J.R., S.N.R. and F.Z. gratefully acknowledge financial support from the Swiss National Science Foundation [Grant\# PP00P2_170589]. A.P., S.V. and J.N.R. were partially funded by Ministry of Education, Science and Technological Development of the Republic of Serbia under Grant No. 173048. T.S. and G.S.S. wish to thank the National Research Foundation of South Africa (UID:111707) for financial support.

Acknowledgments: Authors thank Strahinja Medic from Vetlab Animal Diagnostic Laboratory, Belgrade, Serbia for help and discussion with in vitro bio-distribution experiments.

Conflicts of Interest: The authors declare no conflicts of interest.

\section{References}

1. WHO. World Malaria Report 2018; World Health Organization: Geneva, Switzerland, 2018; Licence: CC BY-NC-SA 2013.2010 IGO.

2. Alonso, P.L.; Brown, G.; Arevalo-Herrera, M.; Binka, F.; Chitnis, C.; Collins, F.; Doumbo, O.K.; Greenwood, B.; Hall, B.F.; Levine, M.M.; et al. A research agenda to underpin malaria eradication. PLoS Med. 2011, 8, e1000406. [CrossRef] [PubMed]

3. Kappe, S.H.; Vaughan, A.M.; Boddey, J.A.; Cowman, A.F. That was then but this is now: Malaria research in the time of an eradication agenda. Science 2010, 328, 862-866. [CrossRef] [PubMed]

4. Kilama, W.; Ntoumi, F. Malaria: A research agenda for the eradication era. Lancet 2009, 374, 1480-1482. [CrossRef]

5. Flannery, E.L.; Chatterjee, A.K.; Winzeler, E.A. Antimalarial drug discovery - approaches and progress towards new medicines. Nat. Rev. Microbiol. 2013, 11, 849-862. [CrossRef] [PubMed]

6. Baragaña, B.; Hallyburton, I.; Lee, M.C.S.; Norcross, N.R.; Grimaldi, R.; Otto, T.D.; Proto, W.R.; Blagborough, A.M.; Meister, S.; Wirjanata, G.; et al. A novel multiple-stage antimalarial agent that inhibits protein synthesis. Nature 2015, 522, 315-320. [CrossRef] [PubMed]

7. Baragaña, B.; Norcross, N.R.; Wilson, C.; Porzelle, A.; Hallyburton, I.; Grimaldi, R.; Osuna-Cabello, M.; Norval, S.; Riley, J.; Stojanovski, L.; et al. Discovery of a quinoline-4-carboxamide derivative with a novel mechanism of action, multistage antimalarial activity, and potent in vivo efficacy. J. Med. Chem. 2016, 59, 9672-9685. [CrossRef] [PubMed]

8. Keough, D.T.; Rejman, D.; Pohl, R.; Zborníková, E.; Hocková, D.; Croll, T.; Edstein, M.D.; Birrell, G.W.; Chavchich, M.; Naesens, L.M.J.; et al. Design of plasmodium vivax hypoxanthine-guanine phosphoribosyltransferase inhibitors as potential antimalarial therapeutics. ACS Chem. Biol. 2018, 13, 82-90. [CrossRef] [PubMed]

9. Muregi, F.W.; Ishih, A. Next-generation antimalarial drugs: Hybrid molecules as a new strategy in drug design. Drug Dev. Res. 2010, 71, 20-32. [CrossRef]

10. Lodige, M.; Lewis, M.D.; Paulsen, E.S.; Esch, H.L.; Pradel, G.; Lehmann, L.; Brun, R.; Bringmann, G.; Mueller, A.K. A primaquine-chloroquine hybrid with dual activity against Plasmodium liver and blood stages. Int. J. Med. Microbiol. 2013, 303, 539-547. [CrossRef]

11. Rossier, J.; Hauser, D.; Kottelat, E.; Rothen-Rutishauser, B.; Zobi, F. Organometallic cobalamin anticancer derivatives for targeted prodrug delivery via transcobalamin-mediated uptake. Dalton Trans. 2017, 46, 2159-2164. [CrossRef]

12. Ruiz-Sanchez, P.; Konig, C.; Ferrari, S.; Alberto, R. Vitamin B(1)(2) as a carrier for targeted platinum delivery: In vitro cytotoxicity and mechanistic studies. J. Biol. Inorg. Chem. 2011, 16, 33-44. [CrossRef] [PubMed]

13. Zelder, F. Recent trends in the development of vitamin B12 derivatives for medicinal applications. Chem. Commun. 2015, 51, 14004-14017. [CrossRef] [PubMed]

14. Nagle, A.; Wu, T.; Kuhen, K.; Gagaring, K.; Borboa, R.; Francek, C.; Chen, Z.; Plouffe, D.; Lin, X.; Caldwell, C.; et al. Imidazolopiperazines: Lead optimization of the second-generation antimalarial agents. J. Med. Chem. 2012, 55, 4244-4273. [CrossRef] [PubMed]

15. Pandey, S.; Agarwal, P.; Srivastava, K.; Rajakumar, S.; Puri, S.K.; Verma, P.; Saxena, J.K.; Sharma, A.; Lal, J.; Chauhan, P.M. Synthesis and bioevaluation of novel 4-aminoquinoline-tetrazole derivatives as potent antimalarial agents. Eur. J. Med. Chem. 2013, 66, 69-81. [CrossRef] [PubMed] 
16. Staines, H.M.; Krishna, S. Treatment and Prevention of Malaria: Antimalarial Drug Chemistry, Action and Use; Springer: Basel, Switzerland, 2012.

17. Mushtaque, M.; Shahjahan. Reemergence of chloroquine (CQ) analogs as multi-targeting antimalarial agents: A review. Eur. J. Med. Chem. 2015, 90, 280-295. [CrossRef] [PubMed]

18. Casagrande, M.; Barteselli, A.; Basilico, N.; Parapini, S.; Taramelli, D.; Sparatore, A. Synthesis and antiplasmodial activity of new heteroaryl derivatives of 7-chloro-4-aminoquinoline. Bioorg. Med. Chem. 2012, 20, 5965-5979. [CrossRef] [PubMed]

19. Chromiński, M.; Lewalska, A.; Karczewski, M.; Gryko, D. Vitamin B12 Derivatives for Orthogonal Functionalization. J. Org. Chem. 2014, 79, 7532-7542. [CrossRef]

20. Chemaly, S.M.; Chen, C.T.; van Zyl, R.L. Naturally occurring cobalamins have antimalarial activity. J. Inorg. Biochem. 2007, 101, 764-773. [CrossRef]

21. Retief, F.P.; Gottlieb, C.W.; Herbert, V. Mechanism of Vitamin B12 uptake by erythrocytes. J. Clin. Invest. 1966, 45, 1907-1915. [CrossRef]

22. Herbert, V.; Sullivan, L.W. Activity of coenzyme B12 in man. Ann. N. Y. Acad. Sci. 1964, 112, 855-870. [CrossRef]

23. Tisman, G.; Vu, T.; Amin, J.; Luszko, G.; Brenner, M.; Ramos, M.; Flener, V.; Cordts, V.; Bateman, R.; Malkin, S.; et al. Measurement of red blood cell-vitamin B12: A study of the correlation between intracellular B12 content and concentrations of plasma holotranscobalamin II. Am. J. Hematol. 1993, 43, 226-229. [CrossRef] [PubMed]

24. Schuster, F.L. Cultivation of pathogenic and opportunistic free-living amebas. Clin. Microbiol. Rev. 2002, 15, 342-354. [CrossRef] [PubMed]

25. Krungkrai, J.; Webster, H.K.; Yuthavong, Y. Characterization of cobalamin-dependent methionine synthase purified from the human malarial parasite, Plasmodium falciparum. Parasitol. Res. 1989, 75, 512-517. [CrossRef] [PubMed]

26. Kirk, K. Membrane transport in the malaria-infected erythrocyte. Physiol. Rev. 2001, 81, 495-537. [CrossRef] [PubMed]

27. Ginsburg, H.; Stein, W.D. How many functional transport pathways does Plasmodium falciparum induce in the membrane of its host erythrocyte? Trends Parasitol. 2005, 21, 118-121. [CrossRef] [PubMed]

28. Saliba, K.J.; Kirk, K. Nutrient acquisition by intracellular apicomplexan parasites: Staying in for dinner. Int. J. Parasitol. 2001, 31, 1321-1330. [CrossRef]

29. Chrominski, M.; Gryko, D. “Clickable” vitamin B12 derivative. Chem. Eur. J. 2013, 19, 5141-5148. [CrossRef] [PubMed]

30. Chrominski, M.; Lewalska, A.; Gryko, D. Reduction-free synthesis of stable acetylide cobalamins. Chem. Commun. 2013, 49, 11406-11408. [CrossRef]

31. Njogu, P.M.; Gut, J.; Rosenthal, P.J.; Chibale, K. Design, synthesis, and antiplasmodial activity of hybrid compounds Based on (2R,3S)-N-Benzoyl-3-phenylisoserine. ACS Med. Chem. Lett. 2013, 4, 637-641. [CrossRef]

32. Ruetz, M.; Salchner, R.; Wurst, K.; Fedosov, S.; Kräutler, B. Phenylethynylcobalamin: A light-stable and thermolysis-resistant organometallic Vitamin B12 derivative prepared by radical synthesis. Angew. Chem. Int. Ed. 2013, 52, 11406-11409. [CrossRef]

33. Vagianou, C.-D.; Stuhr-Hansen, N.; Moll, K.; Bovin, N.; Wahlgren, M.; Blixt, O. ABO blood group antigen decorated giant unilamellar vesicles exhibit distinct interactions with plasmodium falciparum infected red blood cells. ACS Chem. Biol. 2018, 13, 2421-2426. [CrossRef] [PubMed]

34. Fedosov, S.N.; Grissom, C.B.; Fedosova, N.U.; Moestrup, S.K.; Nexø, E.; Petersen, T.E. Application of a fluorescent cobalamin analogue for analysis of the binding kinetics. FEBS J. 2006, 273, 4742-4753. [CrossRef] [PubMed]

35. Slater, A.F.G.; Cerami, A. Inhibition by chloroquine of a novel haem polymerase enzyme activity in malaria trophozoites. Nature 1992, 355, 167-169. [CrossRef] [PubMed]

36. Egan, T.J.; Ross, D.C.; Adams, P.A. Quinoline anti-malarial drugs inhibit spontaneous formation of $\beta$-haematin (malaria pigment). FEBS Lett. 1994, 352, 54-57. [CrossRef]

37. Dorn, A.; Stoffel, R.; Matile, H.; Bubendorf, A.; Ridley, R.G. Malarial haemozoin/ $\beta$-haematin supports haem polymerization in the absence of protein. Nature 1995, 374, 269-271. [CrossRef] [PubMed] 
38. Combrinck, J.M.; Mabotha, T.E.; Ncokazi, K.K.; Ambele, M.A.; Taylor, D.; Smith, P.J.; Hoppe, H.C.; Egan, T.J. Insights into the Role of heme in the mechanism of action of antimalarials. ACS Chem. Biol. 2013, 8, 133-137. [CrossRef] [PubMed]

39. Gupta, P.; Mehrotra, S.; Sharma, A.; Chugh, M.; Pandey, R.; Kaushik, A.; Khurana, S.; Srivastava, N.; Srivastava, T.; Deshmukh, A.; et al. Exploring heme and hemoglobin binding regions of plasmodium heme detoxification protein for new antimalarial discovery. J. Med. Chem. 2017, 60, 8298-8308. [CrossRef] [PubMed]

40. Dorn, A.; Vippagunta, S.R.; Matile, H.; Jaquet, C.; Vennerstrom, J.L.; Ridley, R.G. An assessment of drug-haematin binding as a mechanism for inhibition of haematin polymerisation by quinoline antimalarials. Biochem. Pharmacol. 1998, 55, 727-736. [CrossRef]

41. De Dios, A.C.; Tycko, R.; Ursos, L.M.B.; Roepe, P.D. NMR studies of chloroquine-ferriprotoporphyrin IX complex. J. Phys. Chem. A 2003, 107, 5821-5825. [CrossRef]

42. Crespo, M.P.; Tilley, L.; Klonis, N. Solution behavior of hematin under acidic conditions and implications for its interactions with chloroquine. J. Biol. Inorg. Chem. 2010, 15, 1009-1022. [CrossRef]

43. Sullivan, D.J., Jr.; Gluzman, I.Y.; Russell, D.G.; Goldberg, D.E. On the molecular mechanism of chloroquine's antimalarial action. Proc. Natl. Acad. Sci. USA 1996, 93, 11865-11870. [CrossRef] [PubMed]

44. Sullivan, D.J., Jr.; Matile, H.; Ridley, R.G.; Goldberg, D.E. A common mechanism for blockade of heme polymerization by antimalarial quinolines. J. Biol. Chem. 1998, 273, 31103-31107. [CrossRef] [PubMed]

45. Leed, A.; DuBay, K.; Ursos, L.M.B.; Sears, D.; de Dios, A.C.; Roepe, P.D. Solution structures of antimalarial drug-heme complexes. Biochemistry 2002, 41, 10245-10255. [CrossRef] [PubMed]

46. Natarajan, J.K.; Alumasa, J.N.; Yearick, K.; Ekoue-Kovi, K.A.; Casabianca, L.B.; de Dios, A.C.; Wolf, C.; Roepe, P.D. 4- $\mathrm{N}-$, 4-S-, and 4-O-Chloroquine analogues: influence of side chain length and quinolyl nitrogen pka on activity vs chloroquine resistant malaria. J. Med. Chem. 2008, 51, 3466-3479. [CrossRef] [PubMed]

47. Buller, R.; Peterson, M.L.; Almarsson, O.; Leiserowitz, L. Quinoline binding site on malaria pigment crystal: A rational pathway for antimalaria drug design. Cryst. Growth Des. 2002, 2, 553-562. [CrossRef]

48. Egan, T.J.; Hunter, R.; Kaschula, C.H.; Marques, H.M.; Misplon, A.; Walden, J. Structure-function relationships in aminoquinolines: Effect of amino and chloro groups on quinoline-hematin complex formation, inhibition of $\beta$-hematin formation, and antiplasmodial activity. J. Med. Chem. 2000, 43, 283-291. [CrossRef] [PubMed]

49. Egan, T.J.; Mavuso, W.W.; Ross, D.C.; Marques, H.M. Thermodynamic factors controlling the interaction of quinoline antimalarial drugs with ferriprotoporphyrin IX. J. Inorg. Biochem. 1997, 68, 137-145. [CrossRef]

50. O'Keeffe, D.H.; Barlow, C.H.; Smythe, G.A.; Fuchsman, W.H.; Moss, T.H.; Lilienthal, H.R.; Caughey, W.S. Magnetic and spectroscopic probes for FeOFe linkages in hemin systems. Bioinorg. Chem. 1975, 5, 125-147. [CrossRef]

51. Bowman, T.V.; Zon, L.I. Swimming into the future of drug discovery: in vivo chemical screens in zebrafish. ACS Chem. Biol. 2010, 5, 159-161. [CrossRef]

52. Selakovic, Z.; Tran, J.P.; Kota, K.P.; Lazic, M.; Retterer, C.; Besch, R.; Panchal, R.G.; Soloveva, V.; Sean, V.A.; Jay, W.B.; et al. Second generation of diazachrysenes: Protection of Ebola virus infected mice and mechanism of action. Eur. J. Med. Chem. 2019, 162, 32-50. [CrossRef]

53. Becke, A.D. Density-functional thermochemistry. III. The role of exact exchange. J. Chem. Phys. 1993, 98, 5648-5652. [CrossRef]

54. Zhao, Y.; Truhlar, D.G. The M06 suite of density functionals for main group thermochemistry, thermochemical kinetics, noncovalent interactions, excited states, and transition elements: Two new functionals and systematic testing of four M06-class functionals and 12 other functionals. Theor. Chem. Acc. 2008, 120, 215-241.

55. Zhao, Y.; Truhlar, D.G. Density functionals with broad applicability in chemistry. Acc. Chem. Res. 2008, 41, 157-167. [CrossRef] [PubMed]

56. Hay, P.J.; Wadt, W.R. Ab initio effective core potentials for molecular calculations. Potentials for the transition metal atoms Sc to Hg. J. Chem. Phys. 1985, 82, 270-283. [CrossRef]

57. Hay, P.J.; Wadt, W.R. Ab initio effective core potentials for molecular calculations. Potentials for K to Au including the outermost core orbitals. J. Chem. Phys. 1985, 82, 299-310. [CrossRef]

58. Wadt, W.R.; Hay, P.J. Ab initio effective core potentials for molecular calculations. Potentials for main group elements Na to Bi. J. Chem. Phys. 1985, 82, 284-298. [CrossRef]

59. Hansen, M.B.; Nielsen, S.E.; Berg, K. Re-examination and further development of a precise and rapid dye method for measuring cell growth/cell kill. J. Immunol. Methods 1989, 119, 203-210. [CrossRef] 
60. Trager, W.; Jensen, J.B. Human malaria parasites in continuous culture. Science 1976, 193, 673-675. [CrossRef]

61. Makler, M.T.; Ries, J.M.; Williams, J.A.; Bancroft, J.E.; Piper, R.C.; Gibbins, B.L.; Hinrichs, D.J. Parasite lactate dehydrogenase as an assay for Plasmodium falciparum drug sensitivity. Am. J. Trop. Med. Hyg. 1993, 48, 739-741. [CrossRef]

62. OECD. Test No. 236: Fish Embryo Acute Toxicity (FET) Test; OECD: Paris, France, 2013.

63. Zhang, Y.; Han, L.W.; He, Q.X.; Chen, W.Y.; Sun, C.; Wang, X.; Chen, X.Q.; Wang, R.C.; Hsiao, C.D.; Liu, K.C. A rapid assessment for predicting drug-induced hepatotoxicity using zebrafish. J. Pharmacol. Tox. Met. 2017, 84, 102-110. [CrossRef] [PubMed]

64. He, J.H.; Guo, S.Y.; Zhu, F.; Zhu, J.J.; Chen, Y.X.; Huang, C.J.; Gao, J.M.; Dong, Q.X.; Xuan, Y.X.; Li, C.Q. A zebrafish phenotypic assay for assessing drug-induced hepatotoxicity. J. Pharmacol. Tox. Met. 2013, 67, $25-32$. [CrossRef] [PubMed]

Sample Availability: Samples of the compounds are available from the authors.

(C) 2019 by the authors. Licensee MDPI, Basel, Switzerland. This article is an open access article distributed under the terms and conditions of the Creative Commons Attribution (CC BY) license (http://creativecommons.org/licenses/by/4.0/). 